九州大学学術情報リポジトリ

Kyushu University Institutional Repository

\title{
A GENERIC SYNOPSIS OF THE PONEROID COMPLEX OF THE FAMILY FORMICIDAE IN JAPAN (HYMENOPTERA). PART I. SUBFAMILIES PONERINAE AND CERAPACHYINAE
}

Ogata, Kazuo

https://doi.org/10.5109/2494

出版情報: ESAKIA. 25，pp.97-132，1987-01-31. Entomological Laboratory，Faculty of Agriculture， Kyushu University

バージョン:

権利関係 : 


\title{
A GENERIC SYNOPSIS OF THE PONEROID COMPLEX OF THE FAMILY FORMICIDAE IN JAPAN (HYMENOPTERA). PART I. SUBFAMILIES PONERINAE AND CERAPACHYINAE*
}

\author{
KaZUO OGATA \\ Entomological Laboratory, Faculty of Agriculture, \\ Kyushu University, Fukuoka 812, Japan
}

\begin{abstract}
The poneroid subfamily-complex of the family Formicidae in Japan is revised at genuslevel. This part deals with the subfamilies Ponerinae and Cerapachyinae. Fourteen genera are recognized; 13 belong to the Ponerinae and 1 belongs to the Cerapachyinae. Keys to the all known subfamilies in Japan and to the genera of the Ponerinae are presented. Synonymic list, descriptions of all castes as possible and comment on each genus are given with illustrations.
\end{abstract}

\section{Introduction}

This is a part of the study on the taxonomy of the poneroid subfamily-complex in Japan, Recent studies on Japanese ants have been developed in various fields such as behavioral ecology (e.g. Masuko, 1984), sociobiology (e.g. Yamauchi et al., 1981, 1982), zoogeography (e. g. Terayama, 1982a, b), cytology (e. g. Imai and Kubota, 1972). However, many myrmecologists in Japan face difficulties in identifying the species because the taxonomy of Japanese ants is inadequate. There are few comprehensive studies and workable keys. The latest and the only reference work is the check list published by Onoyama (1980). He listed 145 species (173 forms) of which 85 species (105 forms) belong to 39 genera of the poneroid complex subfamilies. Practically, however, this is little useful to identify the genus or species. This is only a check list and there is no comment on each genus or species. Thus there is a definite need to establish a taxonomic framework.

The primary purpose of the present study is to revise the Japanese ants of the poneroid complex at genus-level. This part, after showing a key to the subfamilies of Japan, treats with the genera of the subfamilies Ponerinae and Cerapachyinae in Japan, including a key to the genera, known synonyms, descriptions and illustrations of each genus and taxonomic notes.

\footnotetext{
* Contribution from the Entomological Laboratory, Faculty of Agriculture, Kyushu University,
} Fukuoka (Ser. 3, No. 221). 


\section{Acknowledgements}

I wish to express my sincere thanks to Prof. Y. Hirashima and Assoc. Prof. K. Morimoto, Kyushu University, for their valuable criticism and constant encouragement. I am much indebted to the following persons for their kindness in offering valuable material and useful information : Dr. T. Abe, Kyoto University ; Mr. Y. Fukumoto, Naha ; Dr. H. T. Imai, National Institute of Genetics ; Prof. M. Kondo, Shiraume Gakuen College ; Mr. M. Kubota, Odawara ; Mr. K. Masuko, Tokyo Metropolitan University ; Assoc. Prof. Y. Murakami, Kyushu University ; Dr. K. Onoyama, Obihiro University of Agriculture and Veterinary Medicine ; Mr. R. Sonobe, Imaichi ; Mr. M. Terayama, University of Tokyo. My thanks are also extended to the following persons and institutions for the loan of specimens : Prof. S. Azuma, University of the Ryukyus ; Dr. I. Hattori, National Institute of AgroEnvironmental Sciences ; Messrs. Y. Miyatake and I. Kanazawa, Osaka Museum of Natural History ; Drs. Y. Kurosawa and M. Owada, National Science Museum (Natural History) ; and Prof. T. Tachikawa, Ehime University.

\section{ThE PONEROID COMPLEX IN JAPAN}

The poneroid complex is one of the two major subfamily-groups proposed by Taylor (1978) who made a modification of Brown's schema of the ant phylogeny (Brown, 1954). This complex is characteristic in having the tubulation of the 4th abdominal segment and dorsally situated stradulatory organ, and comprises 8 subfamilies : Myrmeciinae, Ponerinae, Cerapachyinae, Dor ylinae, Ecitoninae, Leptanillinae, Pseudomyrmecinae and Myrmicinae. Of these, except for the Myrmeciinae and Ecitoninae, 6 subfamilies are found in Japan including the Pseudomyrmecinae which is new to our fauna.

The poneroid complex genera of Japan recognized in the present study are listed in the table, with their world distributions. The demarcation of the zoogeographical regions and the distribution data in this table are adopted from Brown (1973) with a slight modification. According to Brown (1973), northern Japan belongs to the Palearctic Region and southern Japan to the Oriental Region, and the border of these two areas is about $34^{\circ} \mathrm{N}$. This border seems to be related to the thermal aspect in ant distribution. Indeed the $-3.5^{\circ} \mathrm{C}$ isothermal line of the mean minimum temperature of the year, which is known as the northernmost boundary of some tropical ants (Imai, 1971), runs between $33^{\circ} \mathrm{N}$ and $34^{\circ} \mathrm{N}$. But it should be noted that this line is not the definite boundary for all ants. For example, some Holoarctic elements such as Myrmica spp. are found in the mountainous regions of Kyushu and Shikoku.

There is no endemic genus in Japan. This is almost the same for the species-level, though the faunas of the adjacent areas have not been studied adequately.

\section{K EY TO THE SUBFAMILIES OF FoRMiCidAe IN JAPAN (BASED ON WORKER CASTE)}

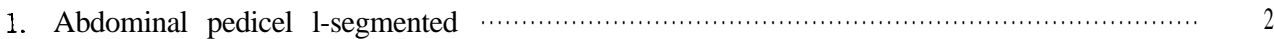

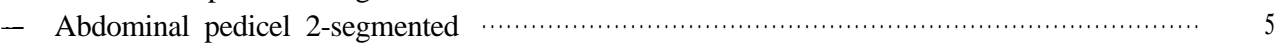

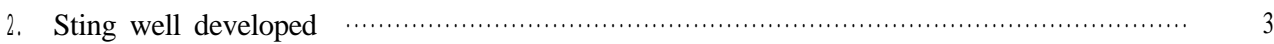

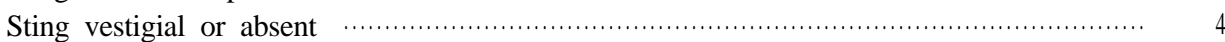

3. Terminal tergum of gaster (7th abdominal tergum) simple, without denticulate margination; anterolateral margin of clypeus without processes 
Table 1. Distribution of the poneroid-complex genera that occur in Japan, with rough estimation of the number of species (modified from Brown, 1973).

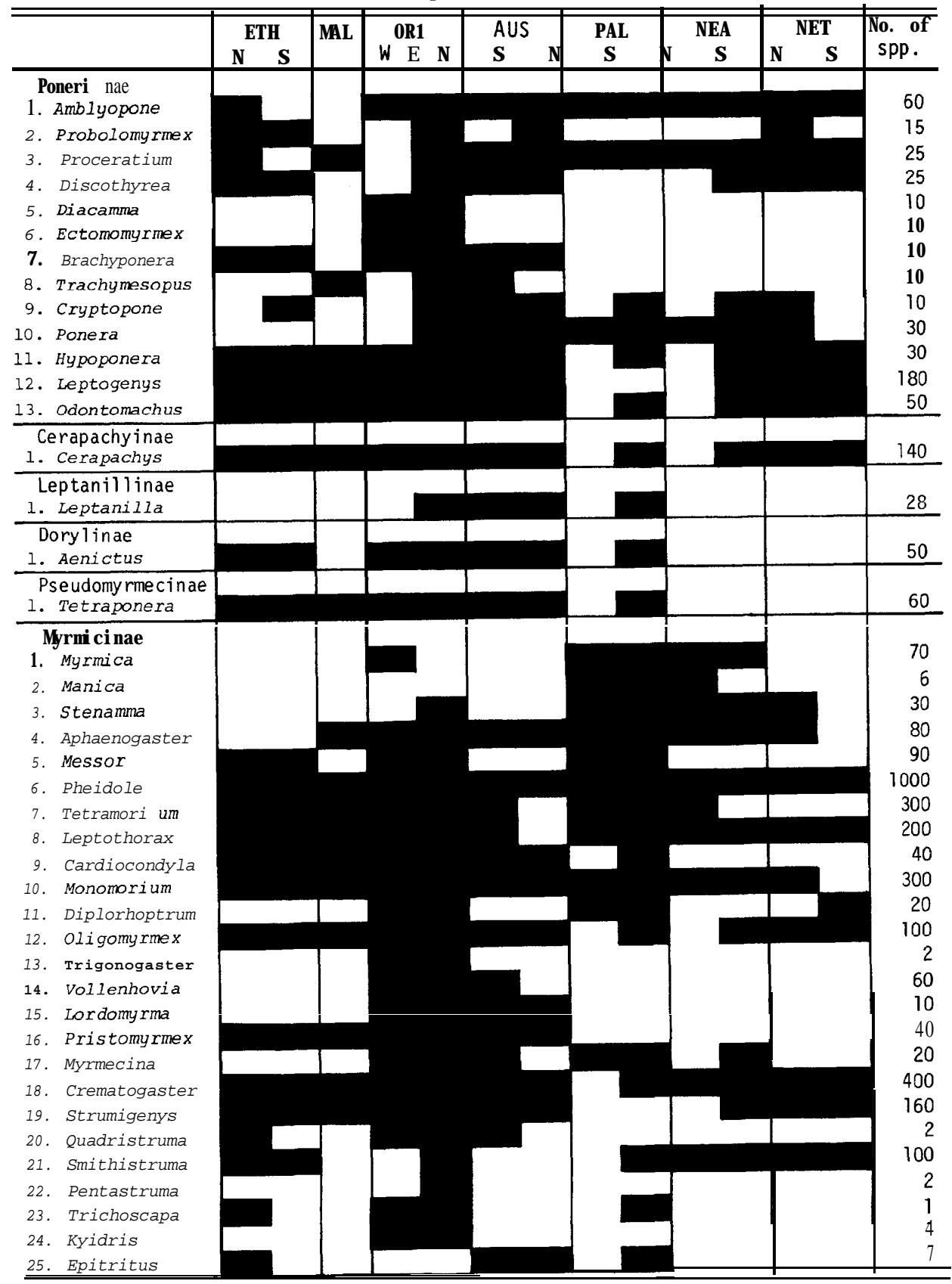

Abbreviations : ETH, Ethiopian ; MAL, Malagasy ;ORI, Oriental ; AUS, Australian ; PAL, Palearctic; NEA, Nearctic ; NET, Neotropical; N, northern subdivision ; S, southern subdivision ; W, western subdivision; E, eastern subdivision. 
Terminal tergum of gaster (7th abdominal tergum) with denticulate margination; anterolateral margin of clypeus with a pair of processes Cerapachyinae Apex of gaster bearing conical structure (acidopore), with circular orifice fringed with hairs (if fringed hairs absent, petiole armed with spines) Formicinae Apex of gaster bearing transverse slit, without fringed hairs; petiole without spines $\cdots$

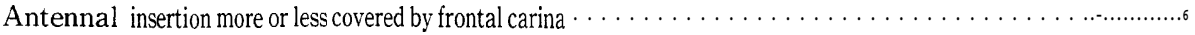

Antennal insertion fully exposed

Eye medium to minute in size (its greatest diameter about $1 / 4 \mathrm{x}$ as long as head length or less) ; middle and hind tibial spurs poorly toothed, simple, or absent ; claws of each

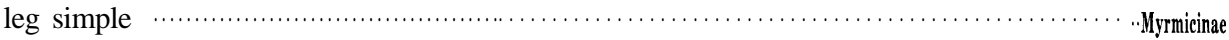

Eye large in size (its greatest diameter about $1 / 3 \mathrm{x}$ as long as head length or more) ; middle and hind tibial spurs distinct and well pectinated ; claws of each leg toothed

..Pseudomyrmecinae

Frontal carina indistinct or absent ; promesonotal area depressed with complete promesonotal suture

Leptanillinae

Frontal carina vertically raised; promesonotal area raised without promesonotal suture dorsally (in Japanese species)

Dorylinae

\section{Subfamily Ponerinae}

Ponerites Lepeletier, 1836, Hist. nat. Insect. Hymen. I : 185.

Ponerinae Dalla Torre, 1893, Cat. Hymen. 7: 13.

Worker : Anterior margin of clypeus without lateral processes above mandibular insertions. Antennal insertion exposed or covered by frontal lobe. Ocelli absent. Promesonotal suture usually complete, but absent in some genera such as Proceratium, Discothyrea and Probolomyrmex. Pectinate tibial spurs present on all legs, but sometimes reduced on middle and hind legs in smaller species. Abdominal pedicel 1-segmented, usually thick and nodiform, without distinct anterior peduncle. Anterior portion of 2 nd gastric ( $=4$ th abdominal) segment constricted. Pygidium without denticulate margination. Sting developed.

Female : General forms of head, legs, petiole and gaster like those of worker, but more massive and ocelli always present. Trunk robust ; epimeral lobe present or absent ; propodeum usually cylindrical with dorsal surface. Fore wing usually with distinct stigma and with 2 closed cubital cells, single closed discoidal and radial cells, but sometimes Rs not reaching apical margin of wing membrane, Rsf 2.3 incomplete or absent, and m-cu absent; Anal lobe of hind wing present or absent:

Male : Eyes and ocelli developed. Mandibles usually small. Pronotum not overhung by mesonotum. Epimeral lobe usually present. Fore and hind wings, propodeum and petiole like those of female. Pygidium sometimes armed with terminal spine. Genitalia usually not retractile ; gonocoxal arm absent.

The subfamily Ponerinae comprises about 50 genera in the world (Brown, 1973), most of which occur in the tropical and subtropical areas. This subfamily is often referred to as a "primitive" ant. Indeed the subfamily has many primitive characters in the wing venation, tibia1 spurs, the abdominal pedicel etc. Some genera, however, have highly specialized characters. Thus the subfamily seems to be heterogenous rather than primitive. Furthermore all the characters delimiting the subfamily are plesiomorphic in the family Formicidae. These facts suggest that the subfamily may be a paraphyletic group. 
In Japan 14 genera of the subfamily have been recorded. However, O dontoponera tram-versa ( $\mathrm{F}$. Smith) reported by Teranishi (1929) from Okinawa Island is now thought to be doubtful, because it has been never collected since his report. It may be a misidentification or the record on the temporally introduced individual, so that this genus is excluded from the present study. Most of the Japanese ponerine ants nest in soil or rotten woods, forming small colonies of a few ten or hundred individuals. They are predaceous or carnivorous, but the detailed biology of each species has been little known.

K EY to the genera of the Ponerinae in Japa N

1. First or second gastric tergum swollen, so that the gaster strongly curved ventrally and

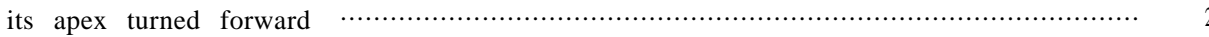
First and second gastric terga not swollen, the gaster not strongly curved ventrally $\cdots \cdots \cdots \cdots \cdot \cdots$

2. Antenna K-segmented, apical segment shorther than the rest of funiculus; anterior margin of clypeus straight or projected in the middle, but not overhanging mandibles

-Proceratiu.

Antenna g-segmented, apical segment bulbous, longer than the rest of funiculus ; anterior margin of clypeus projecting over basal part of mandibles

Discothyrea

3. Connection between petiole and gaster broad; petiole without posterior face ; anterior margin of clypeus dentate

Amblyopone

Connection between petiole and gaster narrow ; petiole with posterior face ; anterior margin of clypeus not dentate

4. Mandibles linear, inserted in the median portion of anterior margin of head ; head more or less constricted behind eyes

Odon tomachus

Mandibles subtriangular, inserted at the sides of anterior margin of head ; head not constricted

5. Frontal carina not covering antennal insertion, but forming vertical lamella; mandibles completely hidden by front-clypeal projection -.Probolomyrme $\dot{x}$ Frontal carina more or less covering antennal insertion ; mandibles exposed

6. Petiolar node with distinct paired spines Diacamma

- Petiolar node without spines

7. Anterior margin of clypeus projecting triangularly ; claws pectinated Leptogeny Anterior margin of clypeus nearly straight or widely rounded ; claws simple $\cdots \cdots \cdots \cdots \cdots \cdots \cdots$

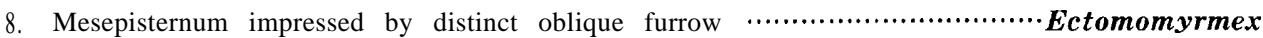

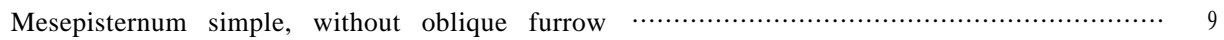

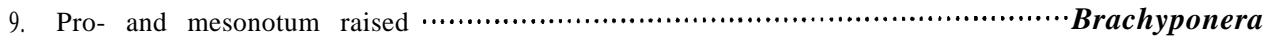

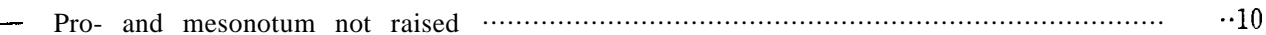

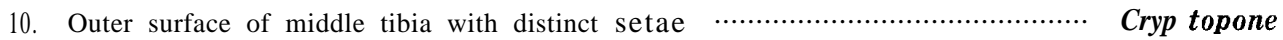

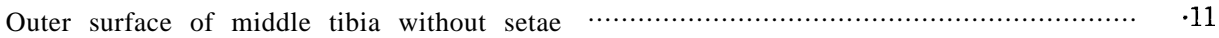

11. Basal portion of mandible with fovea dorsolaterally (in Japanese species) $\cdots$ Trachymesopus

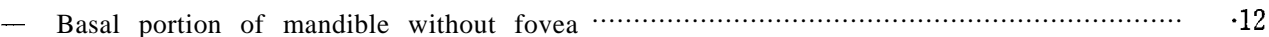

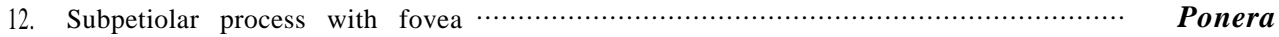

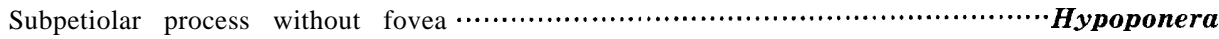




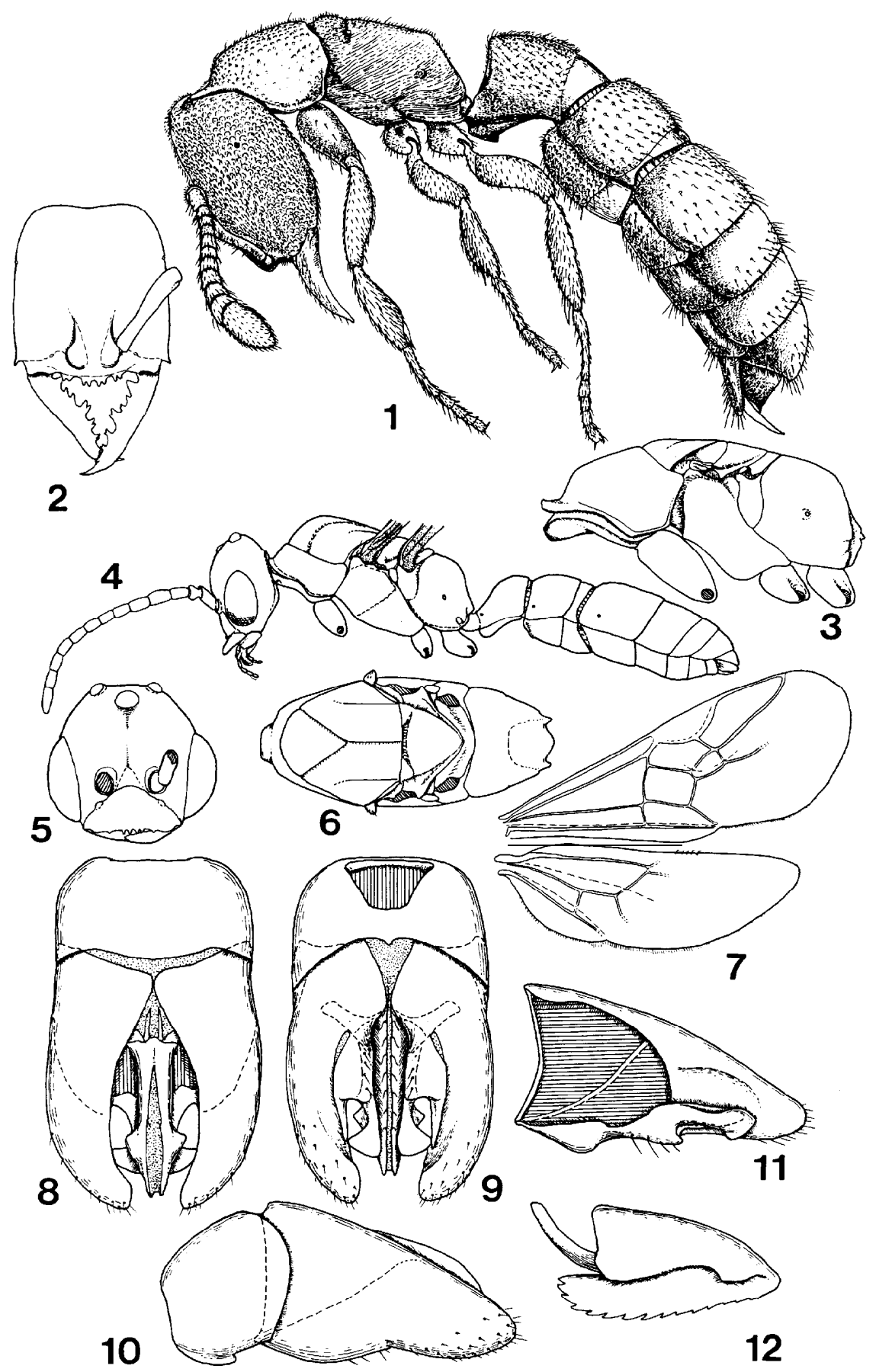

Figs. 1-12. A mblyopone silvestrii (I-2, worker, 3 , female ; 4-12, male) : 1 , profile ; 2 , head ; 3 , trunk ; 4 , profile $; 5$, head $; 6$, trunk, dorsal view ; 7, right wings $; 8$, genitalia, dorsal view ; 9 , ventral view ; 10 , lateral view ; 11 , right paramere and volsella ; 12 , left aedeagal plate. 


\section{Genus Amblyopone Erichson}

(Figs. 1-12)

Amblyopone Erichson, 1842, Arch. Natur. 8 : 260. Type-species : Amblyopone australis Erichson, 1842, op. cit. : 261, by monotypy.

Stigmatomma Roger, 1859, Berl. ent. Z.3: 250. Type-species : Stigmatomma denticulatum Roger, 1859, op. cit. : 251, by subsequent designation of Bingham, 1903.

Arotropus Provancher, 1881, Can. nat. Geol. 12 : 205. Type-species : Arotropus binodosus Provancher, 1881 , loc. cit., by monotypy (= Amblyopone palipes (Haldeman) ).

Xymmer Santschi, 1914, Boll. Lab. 2001. gen. agr. Portici 8:311 (as a subgenus of Stigmatomma). Type-species : Stigmatomma muticum Santschi, 1914, loc. cit., by monotypy.

Fulakora Mann, 1919, Bull. Mus. comp. 2001. Harv. 63 : 279 (as a subgenus of Stigmatomma). Typespecies: Stigmutommu celata Mann, 1919, loc. cit., by original designation.

Neoamblyopone Clark, 1927, in Wheeler, 1927, Proc. Amer. Acad. Arts Sci. $62: 1$ (as a subgenus of Amblyopone). Type-species : Amblyopone clarki Wheeler, 1927, op. cit. : 24, by monotypy.

Protamblyopone Clark, 1927, in Wheeler, 1927, Proc. Amer. Acad. Arts Sci. $62: 1$ (as a subgenus of Amblyopone). Type-species : Amblyopone aberrans Wheeler, 1927, op. cit. : 26, by monotypy.

Lithomyrmex Clark, 1928, J. Proc. R. Soc. West Aust. 14 : 30. Type-species : Lithomyrmex glauerti Clark, 1928, op. cit. : 31, by original designation.

Ericapelta Kusnezov, 1955, 2001. Anz. 154 : 273. Type-species : Ericapelta egregia Kusnezov, 1955, op. cit. : 274, by monotypy.

Worker : Head rectangular, broader anteriorly than posteriorly. Mandible linear, inserted at the anterior corner of clypeus ; apex acute, curved mesally ; inner margin with a single or double rows of dentation. Palp formula varying with species, 5,$3 ; 4,3 ; 3,2 ; 2,2$ (Brown, 1960). Anterior margin of clypeus denticulate. Gena bearing dentiform projection anterolaterally. Frontal carinae covering antennal insertions to form frontal lobes which are usually more or less apart from each other. Antenna 12-segmented for most species, but in some species 9- or ll-segmented ; scape not reaching posterior comer of head; funiculus incrassate but not forming segmental club. Eyes usually present but small, situated posteriorly to the middle of sides of head.

Trunk with complete promesonotal suture ; mesonotum bearing spiracular lobes dorsolaterally ; metanotal groove present or absent ; propodeum not carinate posteriorly. Ventral processes on mesoand metasternum present. Legs short and robust ; tibial spurs of fore and hind legs pectinate, but simple on middle leg; claws simple. Petiole large, cubical, attached to gaster by the whole of its posterior face ; subpetiolar process present but varying in form with species. Anteromedian margination of first gastric sternum not so distinct ; gastric constriction between first and second segments distinct ; sting well developed.

Female : General forms of head and its appendages like those of worker. Eyes large and ocelli present. Trunk with flattened node ; pronotum large, not overhung by mesoscutum, with dorsal surface ; mesoscutellum not overhanging metanotum ; oblique furrow on mesepisternum absent. Propodeum large with elongate dorsal surface. Fore wing with 2 cubital cells, single closed discoidal and radial cells ; anal lobe of hind wing absent. Remainder of body like those of worker.

Male : Head subglobose, compressed. Mandible small, elongate with acute apex. Palp formula 5, 3 in Japanese silvestrii. Clypeus large, bearing denticulation at anterior margin. Gena without lateral tooth. Frontal carinae reduced. Antennal insertion exposed and situated close to posterior margin of clypeus. Antenna 13-segmented, filiform ; scape short. Eyes large ; its inner margin not concave. Ocelli well developed. 
Trunk elongate; notauli and parapsidal furrows present on mesoscutum ; mesoscutellum not overhanging metanotum ; mesepisternum impressed by oblique furrow ; epimeral lobe distinct. Propodeum, wings and legs like those of female. Petiole as in worker but with more rounded comers. Pygidium without terminal spine mesally. Genitalia partly retractile ; basal ring thick; paramere large, subtriangular with oblique inner ridge; digitus lobate,cuspis lamellate; aedeagal plate subtriangular with acute apex and serrate ventral edge.

The genus is found in the world tropics, subtropics and temperate zone, except the Malagasy Region. The genus comprises about 60 species. Recent revisions include those of Brown (1960) and BaroniUrbani (1978).

The broad attachment of the petiole to the gaster shows the primitive states in the Formicidae, so that the genus is sometimes referred to as the most primitive ponerine ant. But the lack of anal lobe in the hind wing, the losses of ventral process of trunk and the oblique furrow on mesepisternum in the female are advanced character states. Therefore it seems that the ant is derived earlier from the ancestral ponerine.

In Japan, only one species has been recorded :

A. silvestrii Fore 1

The species is rather uncommon. Its predatory behavior was reported by Masuko (1981). Onoyama (1976) recognized further 3 species from the Ryukyus, one of which is conspecific with the species reported by Sonobe (1972) from Mt. Kirishima, Kyushu (Onoyama, pers. comm.). I also recognized the occurrence of this species in Cape Manazuru, Honshu. But the taxonomic status of these species have been undetermined.

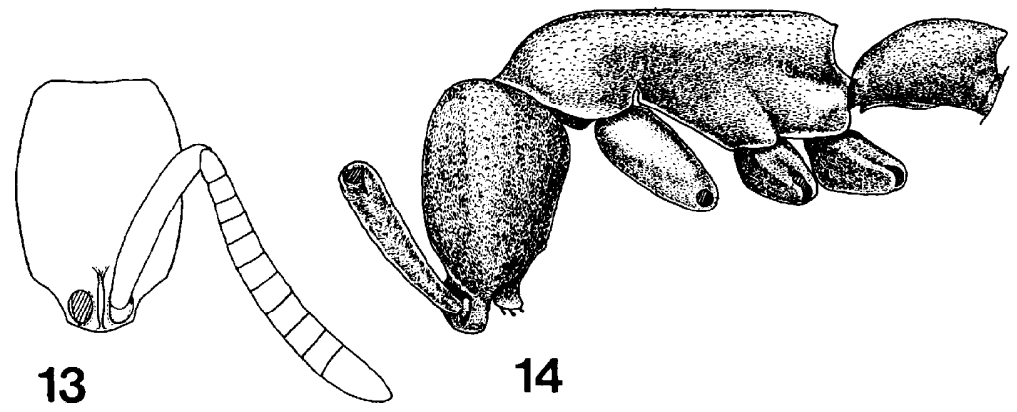

Figs. 13-14. Probolomyrmex sp., worker (from Ishigaki Is., Ryukyus, Y. Fukumoto leg.) : 13, head ; 14, profile.

\section{Genus Probolomyrmex Mayr}

(Figs. 13-14)

Probolomymex Mayr, 1901, Ann. nat. Hofmus. Wien 16 : 2. Type-species : Probolomyrmex filiformis Mayr, 1901, op. cit. : 3, by monotypy.

Escherichia Forel, 1910, 2001. Jb. Syst. 29 : 245. Type-species : Escherichia brevirostris Forel, 1910, op. cit. : 246, by monotypy.

Worker : Head longer than broad. Mandible small, subtriangular, completely covered by frontclypeal projection;masticatory border bearing a distinct apical tooth followed by small denticles; masticatory axis forming right angle to long axis of cranium. Palp formula 4, 2 (Taylor, 1965). 
Clypeus fused to anterior part of frontal region, and forming front-clypeal area which projects over the mandibles as subrectangular shelf. Frontal carinae vertically raised and fused together to form a thin lamella. Antennal insertions exposed, situated on front-clypeal projection anteromedially. Antenna 12-segmented; scape robust, not reaching posterior corner of head; funiculus incrassate, without segmental constrictions, and not forming segmented club.

Trunk slender, arched above, without any sutures dorsally; propodeal declivity weakly marginate. Ventral processes of meso- and metasternum absent. Legs slender; all tibiae each with a single pectinate spur. Petiolar node narrow, strongly arched dorsally and truncate posteriorly ; posterior face sometimes marginate ; subpetiolar process present, but varying in form with species. Anterior portion of first gastric sternum weakly marginate, not forming distinct projection ; acrotergite of second gastric segment small; sting developed.

Female and male : Unknown to me.

This is a small genus including 11 named species in the world, most of which are found in the Old World tropics. Recent revisions include those of Taylor (1965) and Brown (1975).

In Japan Onoyama (1976) reported the occurrence of this genus from Okinawa Island, the Ryukyus, but did not determine the species. I also recognized the genus on the specimen collected by Y. Fukumoto from Ishigaki Island, the Ryukyus. Further, according to Terayama (pers.comm.), the genus was recently known from Okinawa Island. I examined these specimens, and confirmed that there are at least 2 species in the Ryukyus ; one is collected from Okinawa Island and the other is from Ishigaki Island. Both the species are new to science and are to be described in a forthcoming paper by Terayama and Ogata (in prep.). In any case it is apparent that the genus is rare and restricted to the Ryukyus.

\section{Genus Proceratium Roger}

(Figs. 15-29)

Proceratium Roger, 1863, Berl. ent. Z. 7 : 171. Type-species : Proceratium silaceum Roger, 1863, op. cit. : 172 , by monotypy.

Sysphingta Roger, 1863, Berl. ent. Z. 7 : 175. Type-species : Sysphingta micrommata Roger, 1863, op. cit. : 176 , by monotypy.

Sysphincta (!) Mayr, 1865, Reise der... Fregatte Novara Zool. Wien 2: 12, emendation of Sysphingta Roger.

Worker : Head subglobose. Mandible subtriangular with dentate masticator-y margin. Palp formula 4, $3 ; 3,2 ; 2,2$ (Brown, 1958a). Clypeus transverse ; anterior margin straight or with median projection. Antennal insertion situated anteriorly, and in some species demarking a part of anterior margin of clypeus. Frontal carinae partly covering antennal insertions, usually apart from each other. Antenna 12-segmented ; scape reaching posterior corner of head ; funiculus incrassate, apical segment large but not forming distinct bulbous club. Eyes present, but usually reduced to small pigmented spots, situated near or posterior to the middle of sides of head.

Trunk compact, with flattened node; dorsal sutures absent ; propodeum more or less carinate posteriorly; ventral processes of meso- and metasternum absent. Legs short and robust, with pectinate spurs on all tibiae. Petiole varying in form, from thick scale-like to nodiform ; subpetiolar process present. Anterior portion of first gastric sternum weakly marginate; gastric constriction between first and second segments moderate ; second gastric tergum large and swollen ; gastric apex pointed ventrally or in some species directed forward ; sting developed.

Female : General form of head like that of worker, but with larger eyes and developed ocelli. Pronotum with dorsal surface; mesoscutellum not raised, and not overhanging metanotum ; median 


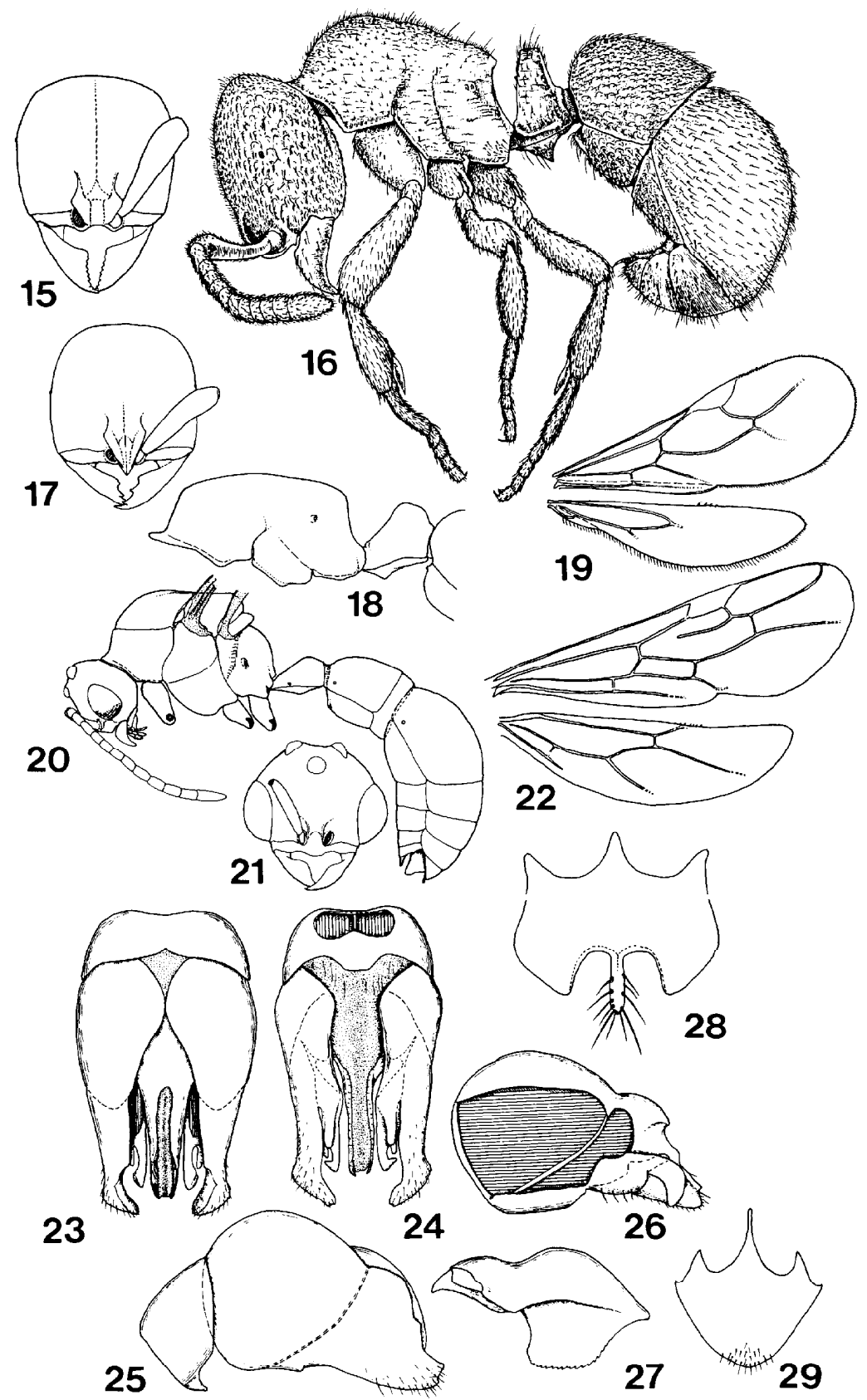

Figs. 15-29. Proceratium spp. (15-18, worker; 19-21, 23-29, male; 22, female): 15, P. japonicum, head ; 16, same, profile ; 17, P.ito $i$, head ; 18, same, trunk ; 19, $P$. japonicum, right wings ; 20, $P$. itoi, profile ; 21 , same, head ; 22, P. watasei, right wings ; $23, P$. itoi, genitalia, dorsal view ; 24 , same, ventral view ; 25 , same, lateral view ; 26 , same, right paramere and volsella ; 27 , same, left aedeagal plate ; 28 , same, subgenital plate, ventral view ; $29, P$. watasei, subgbenital plate, ventral view. 
rised carina developed on mesoscutellum in some species ; oblique furrow present on mesepisternum ; metanotum narrow, somewhat projecting between mesoscutellum and propodeum ; propodeum large, often bearing angulate posterodorsal corners, without distinct dorsal surface. Fore wing venation variable, Rs often not reaching apical margin of wing membrane, free abscissa of Rs (Rsf $2 \cdot 3$ ) absent, and m-cu absent ; anal lobe of hind wing absent. Legs, petiole and gaster like those of worker.

Male : Head subglobose. Mandibles subtriangular, opposable, each with edentate masticatory margin. Palp formula 3, 2 in species examined (ito $i$ and watasei). Clypeus narrow, with weakly projected anterior margin. Frontal carina low, antennal insertion exposed, close to posterior margin of clypeus medially. Antenna 13-segmented;scape short, funiculus filiform. Eyes large ; inner margin not sinuate. Ocelli developed.

Trunk large and robust ; parapsidal furrows impressed on mesoscutum, notauli absent ;mescscutellum not raised, overhanging metanotum ; epimeral lobe indistinct; oblique furrow present on mesepisternum ; propodeum with short and rounded node. Fore and hind wings like those of female. Petiolar node lower and more rounded than those of worker and female. Gaster like that of worker but with less swollen second tergum; pygidium without terminal spine. Hypopygium with distinct median projection at basal margin ; distal margin varying with species. Genitalia partly retractile ; basal ring thick with longitudinal inner ridge dorsomedially; basal porton of paramere large with oblique inner ridge ; apical portion of paramere varying in form with species ; volsella with digitus and cuspis; aedeagal plate subtriangular, with serrate ventral margin.

The genus is distributed from the northern temperate zone to the tropics of the world, including about 30 species. Brown (1958a) gave a revision of the genus. Later in 1974 he summarized the additional species, and more recently (1979) gave some comments on the synonyms, description of further additional species and a key to the New World species.

In Japan the genus has been represented by 3 species :

P. itoi Fore1

P. japonicum Santschi

P.watasei (Wheeler)

As pointed out by Onoyama (1976) there are 2 "forms" in the species which we call "itoi". These "forms" are distinguished by the shape of petiolar node. But more detailed study is needed to decide whether these "forms" represent different species or not.

Proceratines are known as predators of arthropods' eggs (Brown, 1958a). They are almost cryptobiotic, nesting in soil or rotten wood under broadleafed forests. Masuko (1981) briefly reported on the feeding habits of the genus.

\section{Genus Discothyrea Roger \\ (Figs. 30-41)}

Discothyrea Roger, 1863, Berl. ent. Z. 7 : 176. Type-species : Discothyrea testacea Roger, 1863, op. cit. : 177 , by monotypy.

Pseudosysphincta Arnold, 1916, Ann. S. Afr. Mus. 14 : 161. Type-species: Pseudosysphincta poweri Arnold, 1916, op. cit. : 162, by original designation.

Prodiscothyrea Wheeler, 1916, Trans. R. Soc. S. Australia 39 : 33. Type-species: Prodiscothyrea velutina Wheeler, 1916, op. cit. : 34, by monotypy.

Pseudosphincta Wheeler, 1922, Bull. Amer. Mus. nat. Hist. $45: 645$, 762. (Variant spelling of Pseudosysphincta.)

Worker : Head subglobose ; occipital carina low but distinct, extended to ventral surface. 


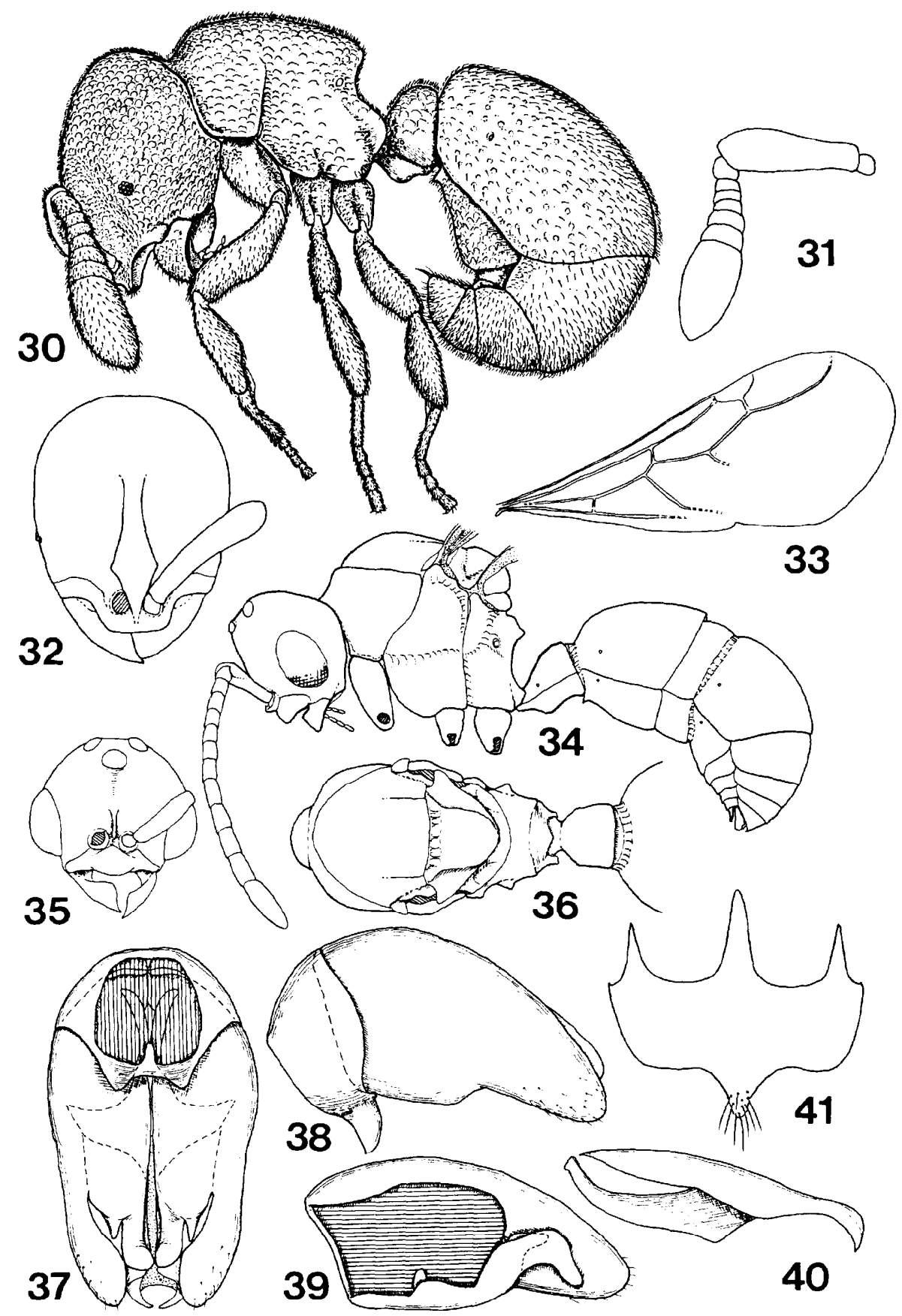

Figs. 30-41. Discothyrea sauteri (30-32, worker; 33-41, male) : 30, profile ; 31, right antenna ; 32, head ; 33, right fore wing; 34 , profile ; 35, head ; 36, trunk, dorsal view ; 37, genitalia, ventral view ; 38, lateral view ; 39, right paramere and volsella ; 40, left aedeagal plate ; 41, subgenital plate, ventral view. 
Mandible small, subtriangular; masticatory margin edentate; inner surface with a series of minute peg-like bristles apically. Palp formula 4, 4 or 4, 3 (Brown, 1958a). Clypeus fused to frontal region medially, forming a subrectangular projection anteriorly which partly covers the mandibles. Frontal carinae fused together to form a median longitudinal platform, with distinct antenna1 scrobes. Antennal insertion almost exposed, situated anteriorly. Antennal segments varying in number, but less than 10 (8 segments in Japanese sauteri); scape short, clavate, and somewhat depressed dorsoventrally ; apical segment large and bulbous, subequal to or longer than total length of the rest of funiculus. Eyes small to minute, situated anterior to the middle of the sides of head.

Trunk compact, lacking any dorsal sutures, with short and flattened node ; posterior declivity of propodeum concave and weakly marginate, with a pair of angulate corners or teeth posterodorsally ; ventral processes absent. Legs short and robust; tibial spurs of all legs pectinate. Petiole small, compressed anteroposteriorly, and broadly attached to gaster ; subpetiolar process low and rounded. Anterior margination of first gastric sternum weakly developed ; first and second gastric terga large and swollen ; gastric apex directed forward; sting developed.

Female : General form of head like that of worker, but with larger eyes and developed ocelli. Trunk rigid ; mesoscutellum overhanging metanotum ; oblique furrow present on mesepisternum ; epimeral lobe indistinct ; propodeum short, with vertical posterior face and posterodorsal angles, lacking definit dorsal surface. Fore wing as in Proceratium; hind wing lacking anal lobe. Legs, petiole and gaster like those of worker.

Male : Head subglobose. Mandibles developed, opposable, each subtriangular in form, with edentate masticatory margin. Palp formula 4, 3 in Japanese sauteri. Clypeus with roundly projected anterior margin. Antennal insertions exposed, close to posterior margin of clypeus medially and separated by thin vertically raised carina. Antenna 13-segmented; scape short, reaching anterior margin of eye. Eyes large ; inner margin not sinuate. Ocelli developed.

Trunk rigid, somewhat compressed anteroposteriorly ; parapsidal furrows present, notauli absent ; mesoscutellum not raised, overhanging metanotum ; oblique furrow impressed on mesepisternum; epimeral lobe absent. The rest of trunk and its appendages like those of female. Petiole longer than those of worker and female, but its attachment to gaster as in worker and female. First and second terga less swollen than those of worker and female; pygidium lacking terminal spine. Hypopygium broader than long, with a distinct median process at basal margin ; distal margin bearing a rounded median process. Genitalia partly retractile ; basal ring thick, with a pair of ventral processes ; paramere without inner oblique ridge ; volsella with large digitus and small cuspis; aedeagal plate with acute apex, but without serrate ventral margin.

The genus includes 26 named species, most of which are found in the world tropics and subtropics. This genus is simillar to Proceratium, in having compact trunk, reduced venation and swollen gastric terga. But some characters such as the number of antennal segments, the bulbous clubs of antennae, the inner setae of mandible and the male genital aedeagus are highly specialized. The revision of the genus includes that of Brown (1958a).

In Japan, the genus has been represented by only one species:

D. sauteri Fore 1

The species was originally described from Taiwan, and is found in south-western Japan, but rather rare. Predatory behavior of the species was briefly reported by Masuko (1981). 


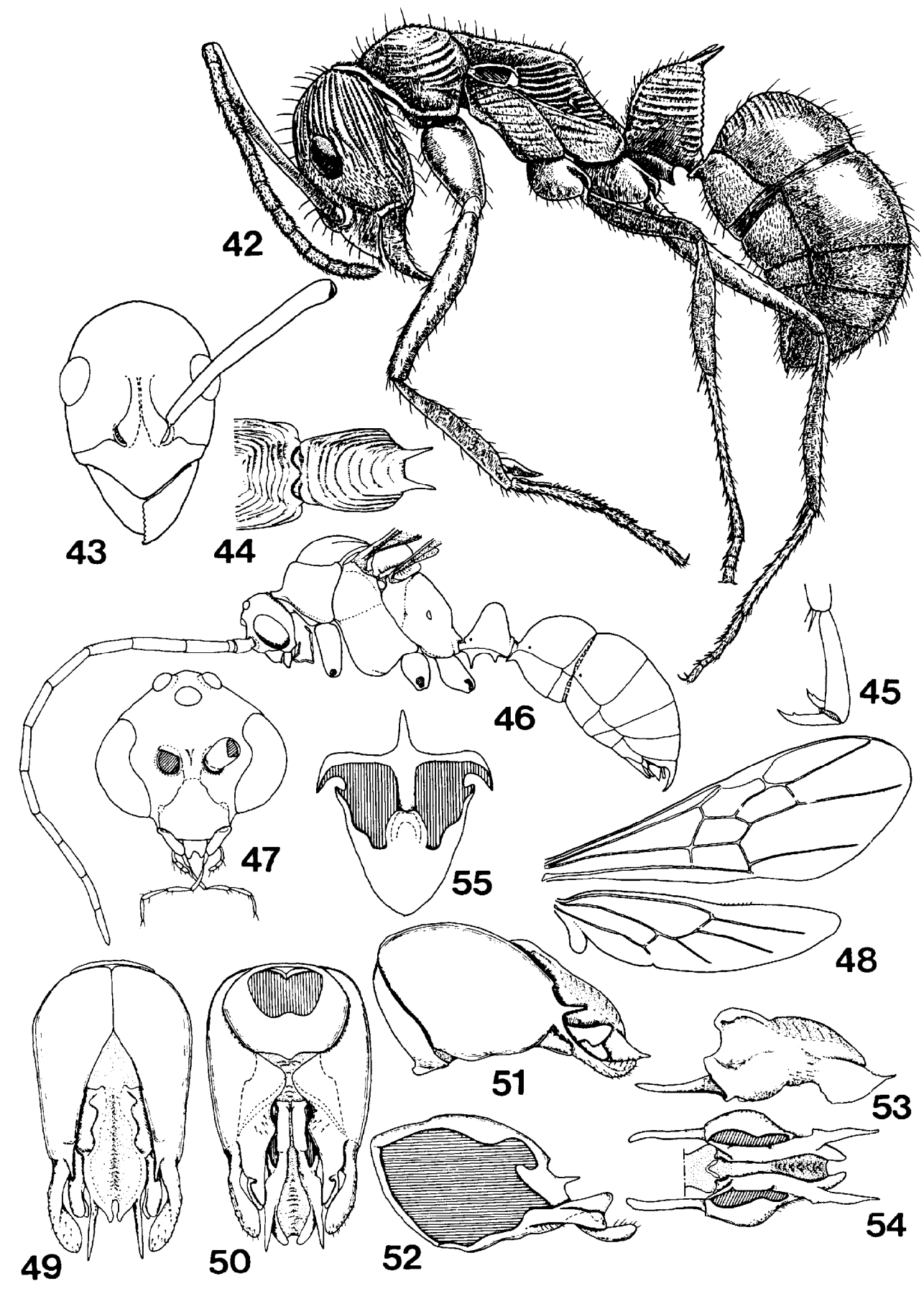

Figs. 42-54. Diacamma rugosum (42-44, worker, 45-54, male) : 42, profile ; 43, head ; 44, petiole, dorsal view ; 45, left hind tarsal claw ; 46, profile ; 47, head ; 48, right wings ; 49, genitalia, dorsal view ; 50, same, ventral view ; 51, same, lateral view ; 52, right paramere and volsella ; 53, left aedeagal plate, lateral view ; 54 , same, ventral view. 


\section{Genus Diacamma Mayr}

(Figs. 42-55)

Diacamma Mayr, 1862, Verh. zool.-bot. Ges. Wien $12: 718$. Type-species : Ponera rugosaLe Guillou, 1841, Ann. Soc. ent. Fr. 10:318, by subsequent designation of Bingham, 1903.

Worker : Head oval, longer than broad. Mandibles large, subtriangular, with dentate masticatory margin. Palp formula 4, 4. Clypeus large, with triangularly produced anterior margin. Antennal insertions covered by frontal carinae which are separated by median furrow. Antenna 12 segmented ; scape long, extending beyond posterior margin of head ; funiculus filiform. Eyes large and convex, situated slightly posterior to middle of head. Occipital carina distinct.

Trunk slender ; promesonotal suture complete ; metanotal groove indistinct ; mesopleural area bearing a hollow which corresponds to wing base ; propodeum without angulate corners and posterior margination ; ventral processes absent. Legs long and slender ; middle and hind tibiae each with a large pectinate spur and a smaller simple spur apically; claws simple. Petiole with a pair of acute spines dorsally ; subpetiolar process developed. Anterior margination of first gastric sternum forming a small but distinct projection; gastric constriction between first and second segments distinct ; sting developed.

Female : Unknown to me (at least queenless in Japanese species).

Male : Head subglobose. Mandibles small, non-opposable with blunt apices. Palp formula 6, 4. Clypeus convex, with almost straight anterior margin. Antennal insertion apart from posterior margin of clypeus. Antenna thick, filiform, 13-segmented ; scape short; second antennal segment smallest, anulli form. Eyes large, inner margin concave. Ocelli well developed.

Trunk large ; mesoscutum convex ; parapsidal furrows present, notauli absent ; mesoscutellum well convex, overhanging metanotum ; oblique furrow impressed on mesepisternum ; epimeral lobe well isolated; ventral processes absent; propodeum large and high. Tibial spurs like those of worker ; claws toothed. Fore and hind wings as in Fig. 48. Petiolar node rounded, without any spines dorsally ; subpetiolar process like that of worker, but with more acute projections. First and second gastric segments and their constriction like those of worker; pygidium with distinct terminal spine. Hypopygium with well sclerotized median projection and a pair of lateral ones at basal margin ; distal half inflected, forming double wall. Genitalia large, partly retractile ; basal ring reduced to narrow ring; paramere spatulate with large basal plate and thin flattened apical portion, bearing acute dorsal tooth at apical third ; volsella with developed digitus and cuspis, both of which are visible in outer lateral view; aedeagal plate elongate, produced laterally and bearing acute apex.

The taxonomy of the genus is in confusion. According to Emery (1911), the genus contains 13 species with 26 infraspecific forms. The genus is found in the Indo-Australian Region.

In Japan only one species has been known from the Ryukyus. Matsumura and Uchida (1926) determined it as D. nugosum geometricum var. anceps Emery. But since many infraspecific forms of D. rugosum, which includes 22 subspecies and varieties, are now seemed to be synonymous, I follow the Taylor's determination in the paper of Fukumoto and Abe (1983). Thus the Japanese species is listed as follows :

\section{D. rugosum (Le Guillou)}

The characteristic hollow of the mesothorax in the worker is made by the manipulation of other worker who cut off the wing bud at the pupal stage (Fukumoto, pers. corn.). The structure of the male genitalia is also characteristic. Judging from the shape of parameres, thier clasping function is reduced or lost. This suggests the possibility of peculiar coupling behavior. Foraging behavior of the 
species was reported by Uezu (1977), Abe and Uezu (1977), and the social organization of colony movement was studied by Fukumoto and Abe (1983).

\section{Genus Ectomomyrmex Mayr}

(Figs. 56-67)

Ectomomyrmex Mayr, 1867, Tijdsch. Ent. $10: 83$. Type-species : Ectomomyrmex javanus Mayr, 1867, op. cit. : 84, by subsequent designation of Bingham, 1903.

Worker : Head subrectangular, somewhat depressed dorsoventrally, with slightly concave posterior margin and subparallel sides, the latter forming longitudinal blunt ridges. Mandible large subtriangular ; masticatory margin dentate, with more of less acute apical tooth. Palp formula 4, 3. Clypeus somewhat narrow, transverse ; anterior margin straight or slightly emarginate. Frontal carinae covering antennal insertions to form frontal lobes and separated by median furrow. Antenna 12-segmented; scape reaching or slightly exceeding beyond posterior margin of head ; funiculus incrassate. Eyes small but distinct, situated at anterior fourth of head dorsolaterally.

Dorsal outline of trunk straight ; promesonotal suture complete; mesonotum with spiracular lobe ; metanotal groove indistinct ; mesepisternum bearing distinct oblique furrow ; ventral pro cesses distinct on meso- and metasternum ; propodeum truncate posteriorly. Legs long ; middle and hind tibiae each with a large pectinate spur and smaller simple spur ; claws simple. Petiole thick and high ; anterior face vertical and convex in dorsal view; posterior face concave with distinct striation; subpetiolar process present. Gaster strongly truncate anteriorly ; first gastric sternum with small but distinct projection anteriorly ; gastric constriction between first and second segments distinct ; sting developed.

Famale : General form of head as in worker, with larger eyes and distinct ocelli. Mesonotum flattened dorsally ; mesoscutellum not overhanging metanotum ; mesepisternum with oblique fur row ; epimeral lobe large and distinct. Fore wing with 2 closed cubital cells, single closed discoidal and radial cells; hind wing lacking anal lobe. Remainder of body and appendages like those of worker.

Male : Head subglobose, somewhat depressed dorsoventrally. Mandibles small, non-opposable, with blunt apices. Palp formula 5, 4. Clypeus large, convex. Antennal insertions apart from posterior margin of clypeus. Antenna 13-segmented, filiform ; scape short. Eyes large ; inner margin concave. Ocelli well developed.

Mesoscutum slightly convex, with distinct notauli and parapsidal furrows; mesoscutellum convex, not overhanging metanotum; oblique furrow impressed on mesepisternum ; epimeral lobe distinct ; ventral processes distinct as in worker and female ; propodeum bearing distinct V-shaped carination on dorsal surface which is derived from anterior margin of propodeum. Legs long ; tibial spurs and claws like those of worker and female. Petiolar node thick, high and with rounded apex ; subpetiolar process low. Gaster not so strongly truncate as in worker ; anterior projection of first gastric sternum and gastric constriction like those of worker and female; pygidium with distinct terminal spine. Hypopygium longer than broad, with small but distinct median process at basal margin and with rounded apex. Genitalia not retractile; basal ring longer than broad; volsella with digitus and cuspis; aedeagal plate subtriangular, with blunt apex and serrate ventral margin.

The genus is found in the Indo-Australian Region, including about 10 species. Brief comment on the genus was given by Brown (1963). Recently the genus is sometimes treated as a junior synonym of Pachycondyla (e. g. Brown, 1973 ; Snelling, 1981 ; Wheeler and Wheeler, 1985). But the concept of the genus Pachycondyla is slightly different from author to author. Here I regard the lists of Brown 


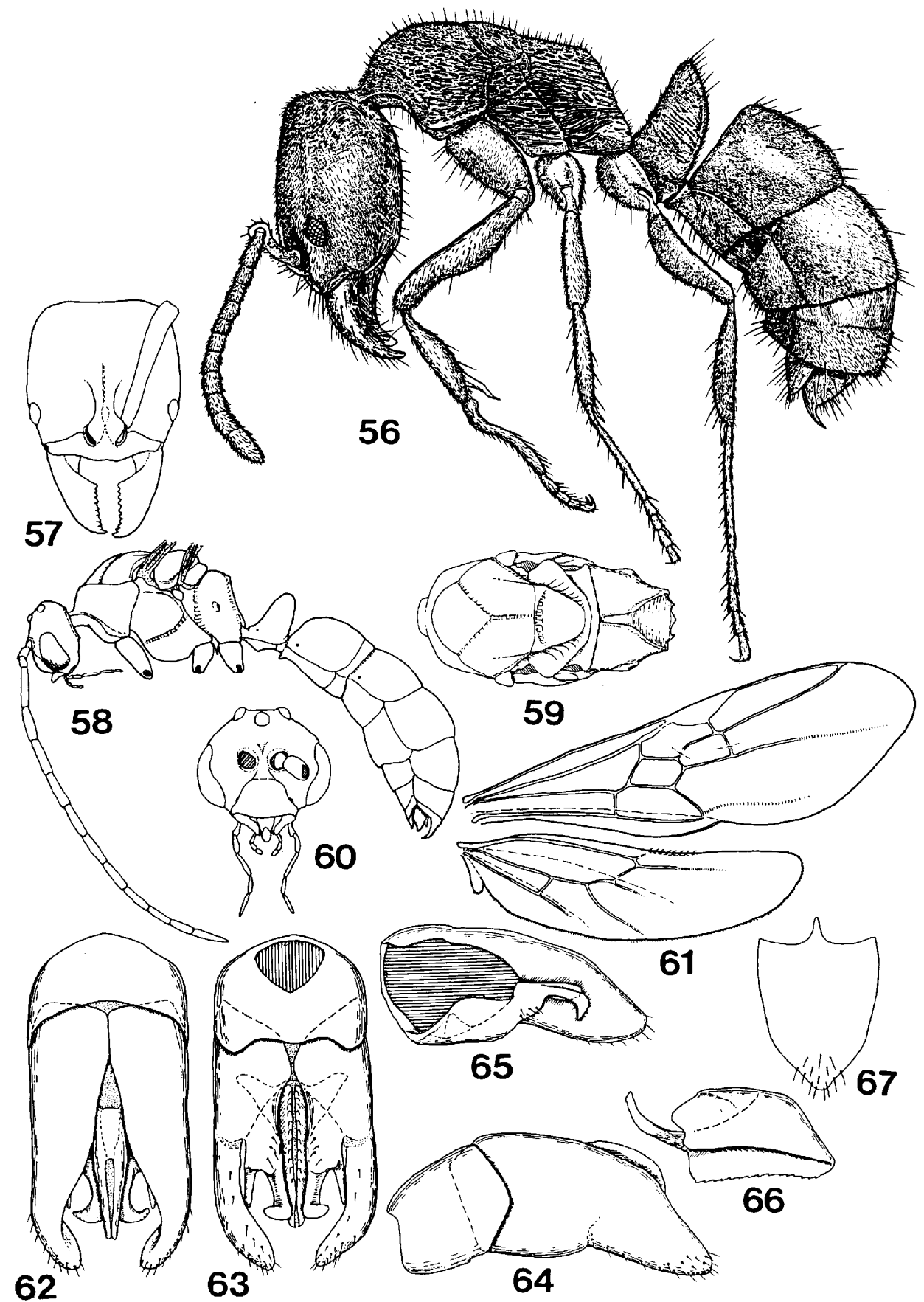

Figs. 56-67. Ectomomyrmex javanus (56-57, worker; 58-67, male) : 56, profile ; 57, head ; 58, profile ; 59 , trunk, dorsal view; 60 , head ; 61 , right wings; 62 , genitalia, dorsal view ; 63, sarne, ventral view ; 64 , same, lateral view ; 65 , right paramere and volsella ; 66 , left aedeagal plate ; 67 , subgenital plate, ventral view. 
etc. as informal because they did not show any taxonomic bases. To avoid unnecessary confusion, it is better to retain the traditional sense until the formal taxonomic change is made. The same is true of the genera Trachymesopus and Brachyponera.

In Japan 2 species have been recorded:

E. sauteri Fore1

E. javanus Mayr

The former species, which was originally described from Taiwan and reported by Teranishi (1933) from the Ryukyus, seems to be doubtful for its taxonomic status and may be a junior synonym of the latter. E. javanus is widely distributed in South-East Asia, and in Japan it is found in Tsushima, southern Kyushu and the Ryukyus. The synonymic list of E. javanus was given by Yasumatsu (1962). The present taxonomic treatment of the species follows that of Ogata et al. (1985).

\section{Genus Trachymesopus Emery}

(Figs. 68-81)

Trachymesopus Emery, 1911, Genera Insect. fasc. $118: 84$, (as a subgenus of Euponera). Typespecies : Formica stigma Fabricius, 1804, Syst. Piez.: 400, by original designation.

Trachymesopus : Wilson, 1958, Bull. Mus. comp. Zool. Harv. 119 : 352. (Raised to genus.)

Worker : Head rectangular. Mandible subtriangular ; basal portion with or without shallow pit on dorsolateral surface ; masticatory margin dentate. Palp formula 3, 3; 4, 3; 4, 4 (4, 4 in Japanese pilosior). Clypeus narrow, transverse ; anterior margin roundly produced with shallow emargination mesally. Antennal carinae covering antennal insertions, forming lobes which are close together and separated by a median furrow. Antenna 12-segmented; scape reaching posterior corner of head or nearly so ; funiculus incrassate. Eyes small to minute, situated anterior fourth of sides of head.

Dorsal outline of trunk straight ; promesonotal suture distinct ; metanotal groove impressed dorsally; propodeum truncate posteriorly, without distinct margination ; ventral processes present on meso- and metasternum. Middle and hind tibiae each with a large pectinate spur and a small simple spur ; claws simple. Petiolar node thick, with vertically raised anterior face and rounded posterolateral comer in lateral view ; subpetiolar process more or less roundly produced. Gaster strongly truncate anteriorly; anteromedian portion of first gastric sternum with small but distinct margination, forming small projection ; gastric constriction distinct ; sting developed.

Female : General form of head as in worker, with larger eyes and small ocelli. Pronotum large ; mesonotum flattened dorsally ; mesoscutellum not overhanging metanotum ; mesepisternum with distinct oblique furrow ; epimeral lobe distinct ; propodeum truncate posteriorly, with dorsal surface. Fore wing with 2 closed cubital cells, single closed discoidal and radial cells; anal lobe present or absent in hind wing (absent in pilosior). Remainder of body and appendages like those of worker.

Male : Head subglobose, somewhat compressed dorsoventrally. Mandibles small, non-opposable, subtriangular with blunt apeces. Palp formula 6,4 in pilosior. Clypeus with straight anterior margin. Antennal insertion apart from posterior margin of clypeus. Eyes large, with concave inner margin. Ocelli developed.

Notauli incompletely present, parapsidal furrows present; mesoscutellum convex, not overhanging metanotum ; oblique furrow impressed on mesepistemum ; epimeral lobe distinct ; propodeum with rounded node; ventral processes and legs as in worker. Petiolar node thick, more rounded than those of worker and female ; subpetiolar process lower than those of worker and female. Anteromedian projection of first gastric sternum and gastric constriction like those of worker and female ; pygidium with distinct terminal spine. Genitalia not retractile; basal ring broader than long; volsella with digitus and cuspis; aedeagal plate subtriangular with serrate ventral margin. 


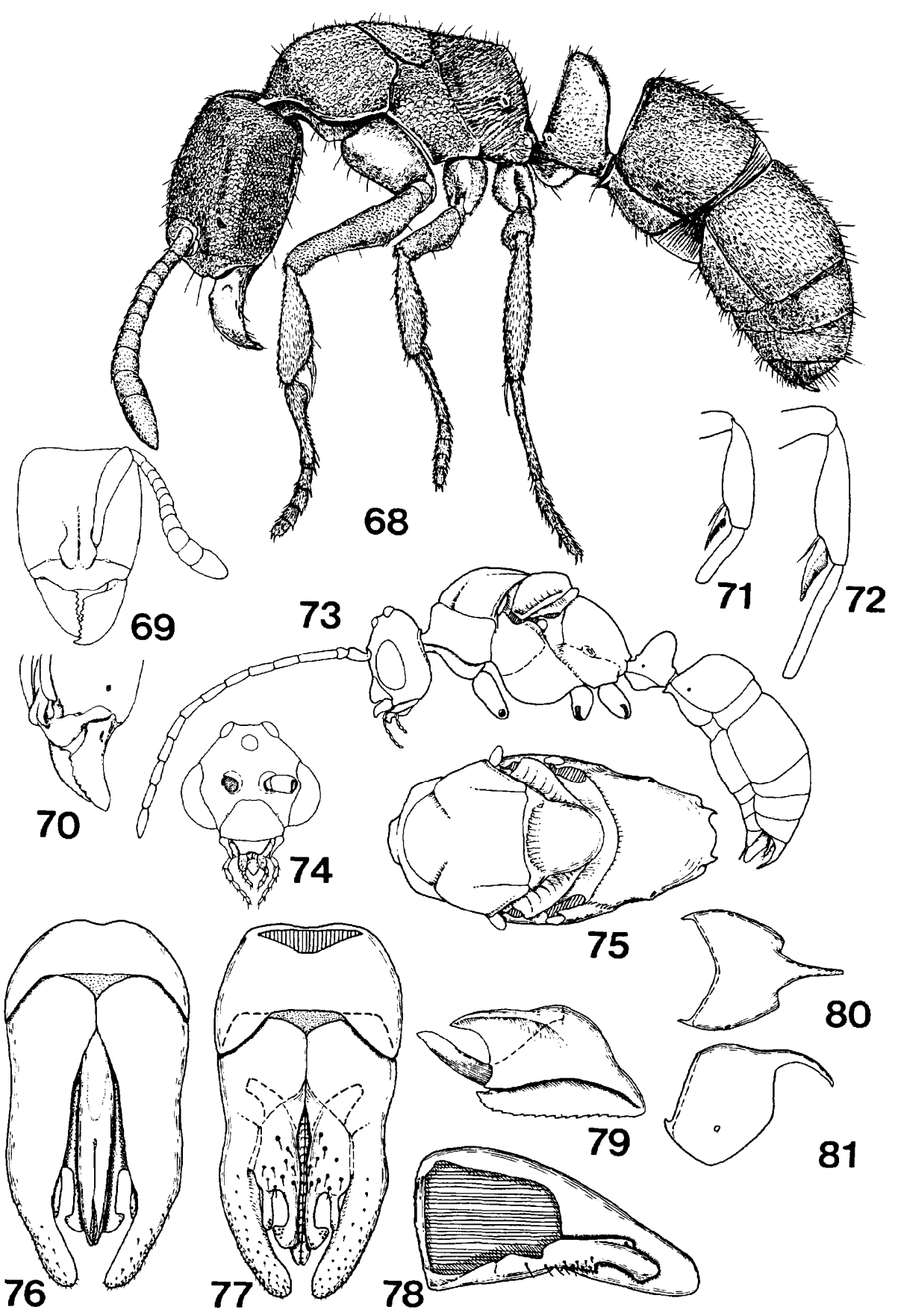

Figs. 68-81. Trachymesopus pilosior (68-72, worker ; 73-81, male) : 68, profile ; 69, head ; 70, mandibles; 71, left middle tibia ; 72, left hind tibia ; 73, profile ; 74, head ; 75, trunk, dorsal view ; 76, male genitalia, dorsal view ; 77, same, ventral view; 78, right paramere and volsella ; 79, left aedeagal plate ; 80, 6th gastric tergum, lateral view ; 81, same, dorsal view. 
The genus is distributed from the warmer temperate zone to the tropics in the world, including some 10 species. Brown (1963) divided the genus into 3 species-groups : the stigma-, the darwini-and the sharpi-groups. Later he suggested the genus to subside back into Pachycondyla (Brown, 1973).

In Japan 2 species have been recorded :

T. pilosior (Wheeler)

T.darwini (Forel)

The former species belongs to the sharpi-group, in having the basal mandibular pit and the 4,4 segmented palp formula in the worker. This species is found in south-western Japan, though the material from the Ryukyus is slightly different from that of Japan proper in the shape of subpetiolar process which is more rounded in the Ryukyuan specimens. Further study on the population of the Ryukyus is needed. T. sharpi has been known by one female only from Iriomote Island, the Ryukyus (Terayama, 1985).

\section{Genus Brachyponera Emery}

(Figs. 82-92)

Brachyponera Emery, 1901, Ann. Soc. ent. Belg. $45: 43$ (as a subgenus of Euponera). Type-species :

Ponera senaarensis Mayr, 1862, Verh. zool.-bot. Ges. Wien $12: 721$, by original designation.

Brachyponera: Wilson, 1958, Bull. Mus. comp. 2001. Harv. 119 : 346. (Raised to genus.)

Worker : Head subrectangular, depressed dorsoventrally. Mandible subtriangular ; masticatory margin dentate, usually consisting of 8-10 denticles; basal portion with shallow and elliptical pit dorsolaterally. Palp formula 3, 3. Clypeus narrow, transverse ; anterior margin roundly produced and shallowly emarginate in the middle. Frontal carinae covering antennal insertions, forming frontal lobes which are separated by median furrow. Antenna 12-segmented ; scape long, extending beyond posterior margin of head ; funiculus incrassate. Eyes small to medium in size, situated anterior fourth of sides of head.

Trunk slender with complete promesonotal suture and distinct metanotal groove ; pronotum with somewhat angulate anterodorsal corners ; pro- and mesonotum raised ; propodeum narrow, depressed with strongly arched node and flat posterior declivity; ventral processes absent on mesosternum but well developed on metasternum. Legs relatively long; middle and hind tibiae each with a large pectinate spur and a smaller simple spur; claws simple. Petiole rather thin, scale-like ; subpetiolar process with a pair of acute teeth posteroventrally. Anteromedian process of first gastric sternum small, covered by posterior articulation process of petiole ; gastric constriction between first and second segments distinct; sting developed.

Female : General form of head as in worker with larger eyes and ocelli. Trunk large with flattened node ; pronotum large ; mesoscutellum less convex, not overhanging metanotum ; oblique furrow impressed on mesepisternum ; epimeral lobe indistinct ; propodeum truncate posteriorly, with dorsal surface ; ventral processes and legs as in worker. Fore wing with 2 closed cubital cells, single closed discoidal and radial cells ; anal lobe present on hind wing. Petiole and gaster like those of worker.

Male : Head subglobose. Mandibles non-opposable, slender and edentate, with acute apices. Palp formula 5, 3. Clypeus convex, with rounded anterior margin. Antenna1 insertions close to posterior margin of clypeus. Antenna 13-segmented, filiform ; scape short, not reaching outer margin of eye. Eyes large ; inner margin sinuate. Ocelli well developed.

Trunk large ; parapsidal furrows and notauli present; mesoscutellum convex, overhanging metanotum ; oblique furrow impressed on mesepisternum ; epimeral lobe distinct ; propodeum with rounded dorsal surface; ventral processes as in worker and female. Legs long and slender ; tibiae 


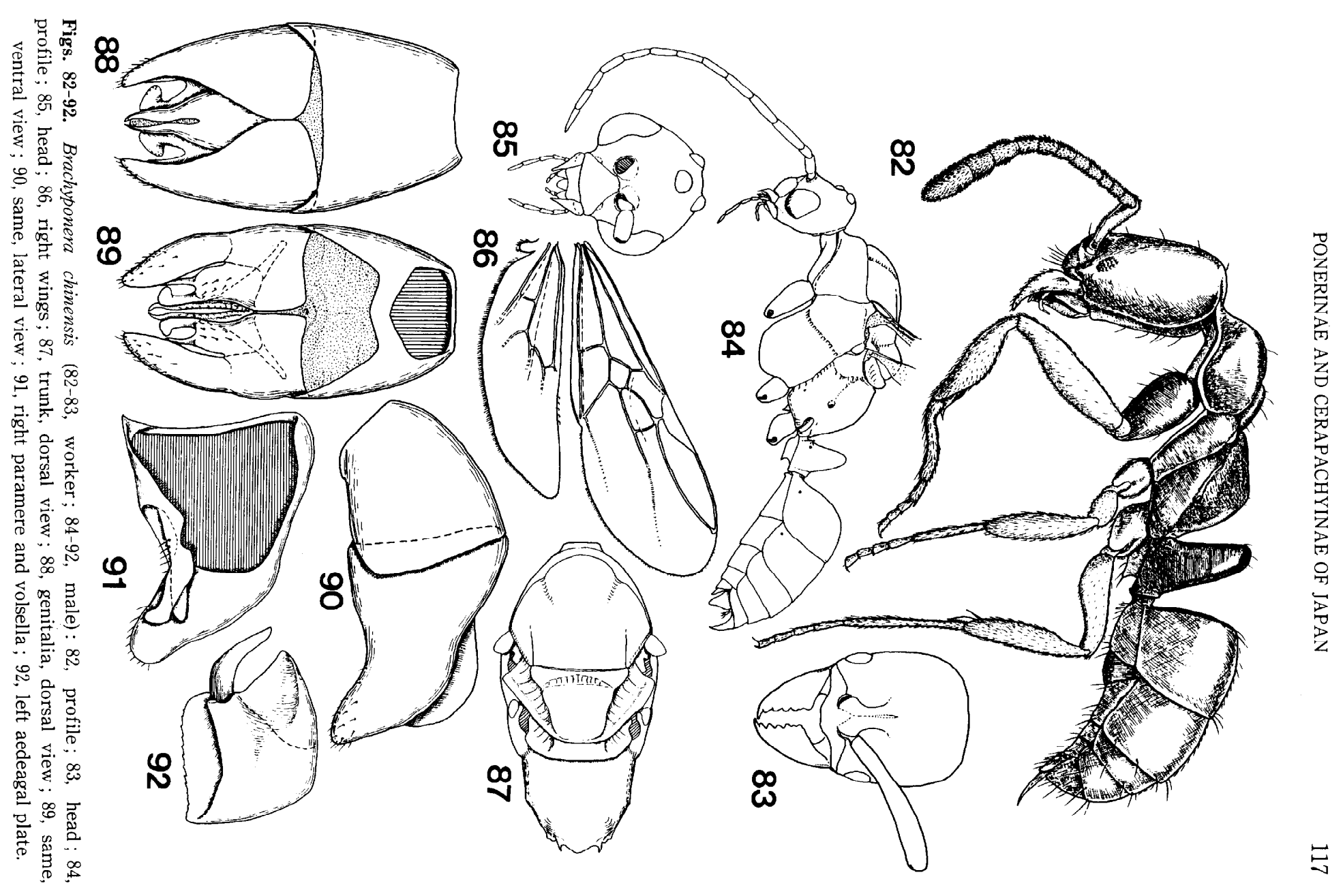


and claws like those of worker.

Petiole thin ; petiolar node more rounded than those of worker and female ; subpetiolar process as in worker and female. Anteromedian projection of first gastric sternum small ; gastric constriction weakly developed ; pygidium with distinct terminal spine. Hypopygium longer than broad, with distinct basal projection medially and rounded apex. Genitalia not retractile ; basal ring longer than broad, nearly as long as paramere in dorsal view ; paramere tapering posteriorly with rounded apex ; volsella with digitus and cuspis; aedeagal plate short, somewhat abruptly descent posteriorly with serrate ventral margin,

The genus includes about 10 species in the Old World tropics and subtropics. Brown (1958b) divided the genus into 3 species-groups: one in Australia, one in Indo-Australia and the other in Africa and Arabia. The genus was briefly revised by Wilson (1958b) for the species of Melanesia and by Brown (1958b) for the species of New Zealand. But the species occurring in Asia remain unstudied.

In Japan the genus has been represented by a single named species :

B. chinensis (Emery)

The species is one of the commonest ants in south-western Japan, nesting in soil and rotten wood. There is another species occurring in the Ryukyus, though the taxonomic status is undetermined. This species is very similar to chinensis but distinguished by the smooth propodeal declivity in the worker, the elongate mandibles and the blackish body color in the male.

\section{Genus Cryptopone Emery}

(Figs. 93-102)

Cryptopone Emery, 1892, Ann. Soc. ent. Fr. $61: 275$. Type-species : Cryptopone testucea Emery, 1893, ibid. $62: 240$, by subsequent designation of Wilson, 1958 b.

Worker : Head subrectangular, longer than broad. Mandibles subtriangular ; basal portion with a pit on dorsolateral surface ; masticatory margin dentate. Palp formula 2, 2 or less (Brown, 1963), in Japanese species 0, 2. Clypeus convex in the middle ; anterior margin roundly produced. Antenna1 carinae covering antennal insertions to form frontal lobes which are close each other and separated by median furrow. Antenna 12-segmented ; scape not reaching posterior corner of head ; funiculus incrassate. Eyes minute or absent, if present, situated on sides at the level of antennal insertions.

Dorsal outline of trunk straight in lateral view ; promesonotal suture complete, promesonotal groove indistinctly impressed ; ventral processes absent. Legs short ; middle and hind tibiae each with a large pectinate spur and a small simple one ; middle tibia with short and stout spinules on external surface ; claws simple. Petiole thick ; subpetiolar process thin, lamelliform. First gastric sternum with weak margination anteriorly, not forming projection ; gastric constriction between first and second segments distinct; sting developed.

Female : General form of head as in worker, with larger eyes and small ocelli ; pronotum large ; mesonotum flattened dorsally ; mesoscutellum not overhanging metanotum ; mesepisternum with oblique furrow ; epimeral lobe small but well isolated ; propodeum truncate posteriorly. Fore wing with closed radial cell ; hind wing lacking anal lobe. Remainder of body and appendages like those of worker.

Male : Head subglobose. Mandibles non-opposable, subtriangular with blunt apices. Palp formula 2, $\mathbf{2}$ in Japanese species. Clypeus large, convex in the middle. Antenna1 insertion apart from posterior margin of clypeus. Antenna 13-segmented, filiform ; scape short. Eyes large, with slightly concave inner margin. Ocelli developed.

Pronotum relatively small ; parapsidal furrows present, notauli absent ; mesonotum depressed ; 


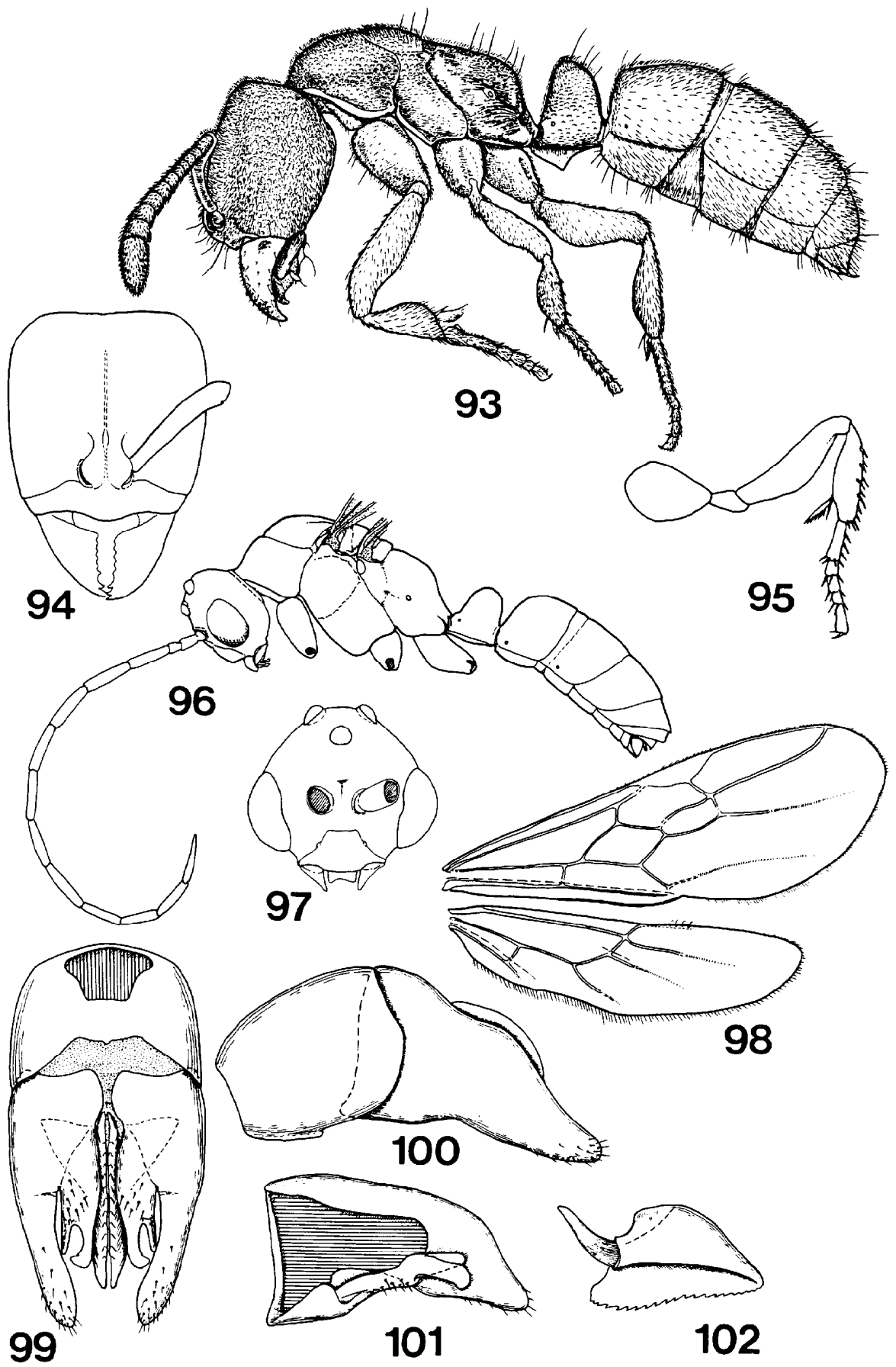

Figs. 93-102. Cryptopone sauteri (93-95, worker; 96-102, male) : 93, profile ; 94, head ; 95, left middle leg ; 96, profile ; 97, head ; 98, right wings; 99, genitalia, ventral view ; 100, same, latteral view ; 101, right paramere and volsella ; 102, left aedeagal plate. 
mesoscutellum not overhanging metanotum ; oblique furrow impressed on mesepisternum ; epimeral lobe distinct ; ventral processes absent; propodeum with rounded dorsal surface, without marginate declivity. Legs long; middle tibia lacking spinules on extensor surface ; tibial spurs of middle and hind legs like those of worker and female. Fore and hind wings like those of female. Petiolar node thin, smaller than those of worker and female and with rounded comers; subpetiolar process lacking. Anteromedian portion of first gastric sternum and gastric constriction as in worker and female ; pygidium with terminal spine. Genitalia partly retractile ; basal ring longer than broad; paramere tapering, with rounded apex ; volsella with digitus and cuspis; aedeagal plate subtriangular with serrate ventral margin.

The genus includes about 10 species, most of which are found in the tropical and subtropical Asia. Wilson (1958b) redefined the genus and revised the Melanesian species. Brown (1963) gave an additional comment on the genus.

In Japan the genus has been represented by a single species :

C. sauteri Fore1

The species nests in rotten wood, and is rather common in the floor of broadleafed forest of southwestern Japan.

\section{Genus Ponera Latreille}

(Figs. 103-112)

Ponera Latreille, 1804, Nouv. Dict. Hist. Nat. 24 : 178. Type-species : Formica coarctata Latreille, 1802, Bull. Sci. Soc. Phil. (57) : 65, by subsequent designation of Westwood, 1840.

Pseudocryptopone Wheeler, 1933, Amer. Mus. Nov. 672: 12. Type-species :Cryptopone tenuis

Emery, 1900, Termes. Füzet. $23: 321$, by original designation.

Solenopone Wheeler, 1933, Amer. Mus. Nov. 672 : 19. Type-species: Ponera seleophora Emery, 1900, Termes. Ftizet. $23: 317$, by original designation,

Worker : Head subrectangular, longer than broad. Mandible subtriangular ; masticatory margin dentate with three larger apical teeth followed by a series of minute denticles. Palp formula 2, 2. Clypeus narrow, transverse ; anterior margin slightly convex with a small median lobe. Frontal carinae almost covering antennal insertions to form frontal lobes which are close each other and separated by median furrow. Antenna 12-segmented ; scape reaching or slightly exceeding beyond posterior margin of head; funiculus incrassate; apical segment large, subequal to two preceding segments together in length.

Dorsal outline of trunk straight; promesonotal suture complete; metanotal groove weakly impressed ; propodeal declivity with or without weak margination; ventral processes present on meso- and metasternum. Legs short ; middle and hind tibiae each with a single pectinate spur ; claws simple. Petiolar node thick; anterior face thick, posterior face straight or slightly concave in dorsal view ; subpetiolar process with circular pit and angulate posteroventral corner. First gastric sternum marginate anteromedially, but not forming projection ; gastric constriction between first and second segments distinct ; sting developed.

Female : General form of head as in worker, with larger eyes and small ocelli. Pronotum large ; mesonotum flat dorsally; mesoscutellum not overhanging metanotum ; mesepisternum with oblique furrow ; epimeral lobe small but distinct ; propodeum truncate posteriorly, with rounded dorsal surface. Remainder of body and appendages like those of worker.

Male : Head subglobose, somewhat depressed dorsoventrally. Mandibles reduced, non-opposable, with more or less acute apices. Palp formula 3, 2 in Japanese species. Clypeus convex ; anterior 


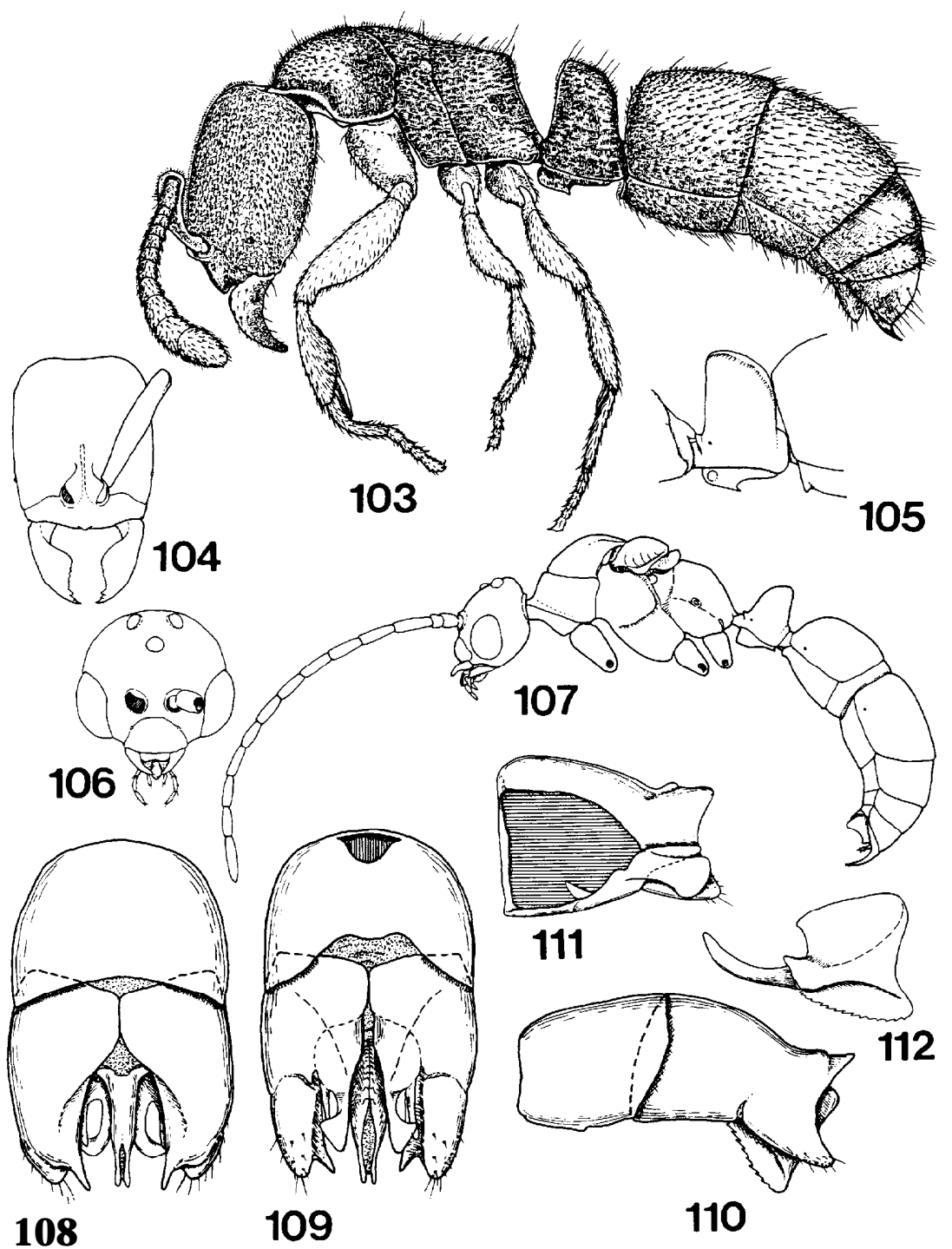

Figs. 103-112. Ponera scabra (103-105, worker ; 106-112, male) : 103, profile ; 104, head ; 105, petiole ; 106, head ; 107 , profile ; 108 , genitalia, dorsal view ; 109 , same, ventral view ; 110, same, lateral view ; 111 , right paramere and volsella ; 112, left aedeagal plate.

margin widely rounded. Antennal insertion exposed and apart from posterior margin of clypeus. Antenna 13-segmented, filiform; scape short not reaching outer margin of eye. Eyes large, inner margin not concave. Ocelli present but relatively small.

Parapsidal furrows present, notauli absent; mesoscutellum convex, not overhanging metanotum ; mesepisternum with oblique furrow ; epimeral lobe fused to mesepisternum ; ventral processes and legs like those of worker. Petiolar node thick as in worker, but with more rounded corners; subpetiolar process present, but lower and more rounded than those of worker and female ; pit on subpetiolar process absent. Anteromedian margination of first gastric sternum and gastric constric- 
tion like those of worker ; pygidium with distinct terminal spine. Hypopygium with distinct basal projection medially and with rounded apex. Genitalia not retractile, somewhat depressed dor soventrally ; basal ring longer than broad ; paramere with blunt process posterodorsally, and with rounded apex ; volsella with digitus and cuspis; aedeagal plate higher than long, with concave apical margin and serrate ventral margin.

The genus was revised by Taylor (1967) who recognized 28 species in the world. Most of the species are found in the Indo-Australian Region.

In Japan Onoyama (1980) listed 5 species of the genus recorded to date, 2 of which, excoecata Wheeler and nippona Santschi, are now transferred to Hypoponera. Thus the genus is represented by 3 species in Japan :

$P$. japonica Wheeler

P. scabra Wheeler

P. yakushimensis Tanaka

The former 2 species, $P$. japonica and $P$. scabra, are rather common in south-western Japan. All the species occurring in Japan are found in the leaf-litter or rotten wood.

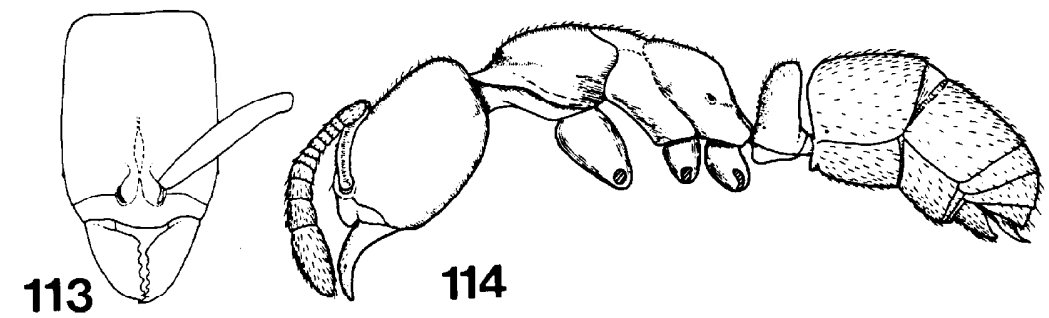

Figs. 113-114. Hypoponera excoecata, worker : 113, head ; 114, profile.

\section{Genus Hypoponera Santschi}

(Figs. 113-114)

Hypoponera Santschi, 1938, Bull. Soc. ent. Fr. 43 : 78 (as a subgenus of Ponera Latreille). Typespecies : Ponera abeillei André, 1881, Ann. Soc. ent. Fr. $6: 48$, by original designation.

Hypoponera : Taylor, 1967, Pac. Ins. Mon. 13 : 9. (Raised to genus.)

Worker : Head subrectangular. Mandible subtriangular, with dentate masticatory margin. Palp formula 0, 2 in Japanese species. Clypeus narrow, transverse, convex in the middle ; anterior margin rounded, Frontal carinae forming frontal lobes which cover antennal insertions and are close each other. Median furrow impressed in the middle. Antenna 12-segmented ; scape reaching posterior comer of head or nearly so ; funiculus incrassate. Eyes minute, situated anterior fourth of sides of head, or absent.

Dorsal outline of trunk straight ; promesonotal suture complete; metanotal groove weakly impressed ; propodeum truncate posteriorly, without distinct margination ; ventral processes absent on mesosternum but present on metasternum. Middle and hind tibiae each with a single pectinate spur ; claws simple. Petiolar node somewhat thin, with half-elliptical tip in frontal view ; subpetiolar process present, without pit. Anteromedian margination of first gastric sternum low but distinct ; gastric constriction between first and second segments distinct; sting developed.

Female : General form of head as in worker, with larger eyes and developed ocelli. Pronotum 
large ; mesoscutellum not overhanging metanotum; oblique furrow impressed on mesepisternum ; epimeral lobe small, indistinct; propodeum truncate posteriorly, with dorsal surface. Fore wing simillar to that of Ponera; hind wing lacking anal lobe. Remainder of body and appendages like those of worker.

Male: Unknown to me.

The genus is distributed in almost all the zoogeographical regions. Taylor (1967) revised the genus and treated 19 species, but suggested to contain about 100-120 species in the world.

In Japan, only one species has been recorded (Onoyama, 1980), but 2 species are transferred to the present genus from Ponera. Thus the genus Hypoponera is represented by 3 species :

H. excoecata (Wheeler) n. comb.

H. nippona (Santschi) n. comb.

H. zwaluwenburgi (Wheeler)

Further there are a few more species which remain undetermined (cf. Onoyama, 1976). The genus is common in the Berlese funnel sample. Nesting sites of the genus have wide range from the forest zone to open land.

\section{Genus Leptogenys Roger}

(Figs. 115-119)

Leptogenys Roger, 1861, Berl. ent. Z. 5 : 41. Type-species : Leptogenys falicigera Roger, 1861, op. cit. : 42, by subsequent designation of Bingham, 1903.

Lobopelta Mayr, 1862, Verh. zool.-bot. Ges. Wien $12: 733$. Type-species : Ponera diminuta F. Smith, 1857, Cat. Hym. Brit. Mus. $6: 69$, by subsequent designation of Bingham, 1903.

Lobopelta : Emery, 1911, Genera Insect. fasc. 118 : 101 (as a subgenus of Leptogenys).

Machaerogenys Emery, 1911, Genera Insect. fasc. 118: 100 (as a subgenus of Leptogenys). Typespecies : Leptogenys truncatirostris Forel, 1897, Abh. Senckenb. naturforsch. Ges. 21 : 195, by original designation.

Dorylozelus Forel, 1915, Ark. Zool. 9 : 24. Type-species : Dorylozelus mjobergi Forel, 1915, op. cit. : 25 , by monotypy.

Microbolbos Donisthorpe, 1948, Entomologist, 81 : 170. Type-species : Microbolbos testaceus

Donisthorpe, 1948, loc. cit., by original designation.

Worker : Head longer than broad, somewhat tapering posteriorly with low but distinct occipital carina. Mandible varying in form, from elongate to triangular (short linear in Japanese species) ; masticatory margin edentate. Palp formula 4, 4. Clypeus with longitudinal median carina ; anterior margin usually produced in the middle. Frontal carinae partly covering antennal insertions, forming frontal lobes which are close each other and separated by median furrow. Antenna 12-segmented ; scape long, extending beyond posterior margin of head ; funiculus incrassate. Eyes varying in size, usually distinct, situated slightly anterior to the middle of sides of head.

Trunk slender; promesonotal suture complete ; pro- and mesonotal areas slightly raised ; metanotal groove impressed ; propodeum elongate, with arched node; ventral processes of meso- and metasternum distinct. Legs long; middle and hind tibiae each with a large pectinate spur and a smaller simple spur ; claws of all legs usually pectinate. Petiole varying from thin to thick nodiform (elongate subrectangular in Japanese confucii); subpetiolar process small, projecting on antero ventral portion. Anteromedian portion of first gastric sternum with small but distinct projection ; gastric constriction between first and second segments usually distinct ; sting developed.

Female : Unknown to me.

Male : Head subglobose, slightly longer than broad. Mandibles reduced to form small subtrian- 


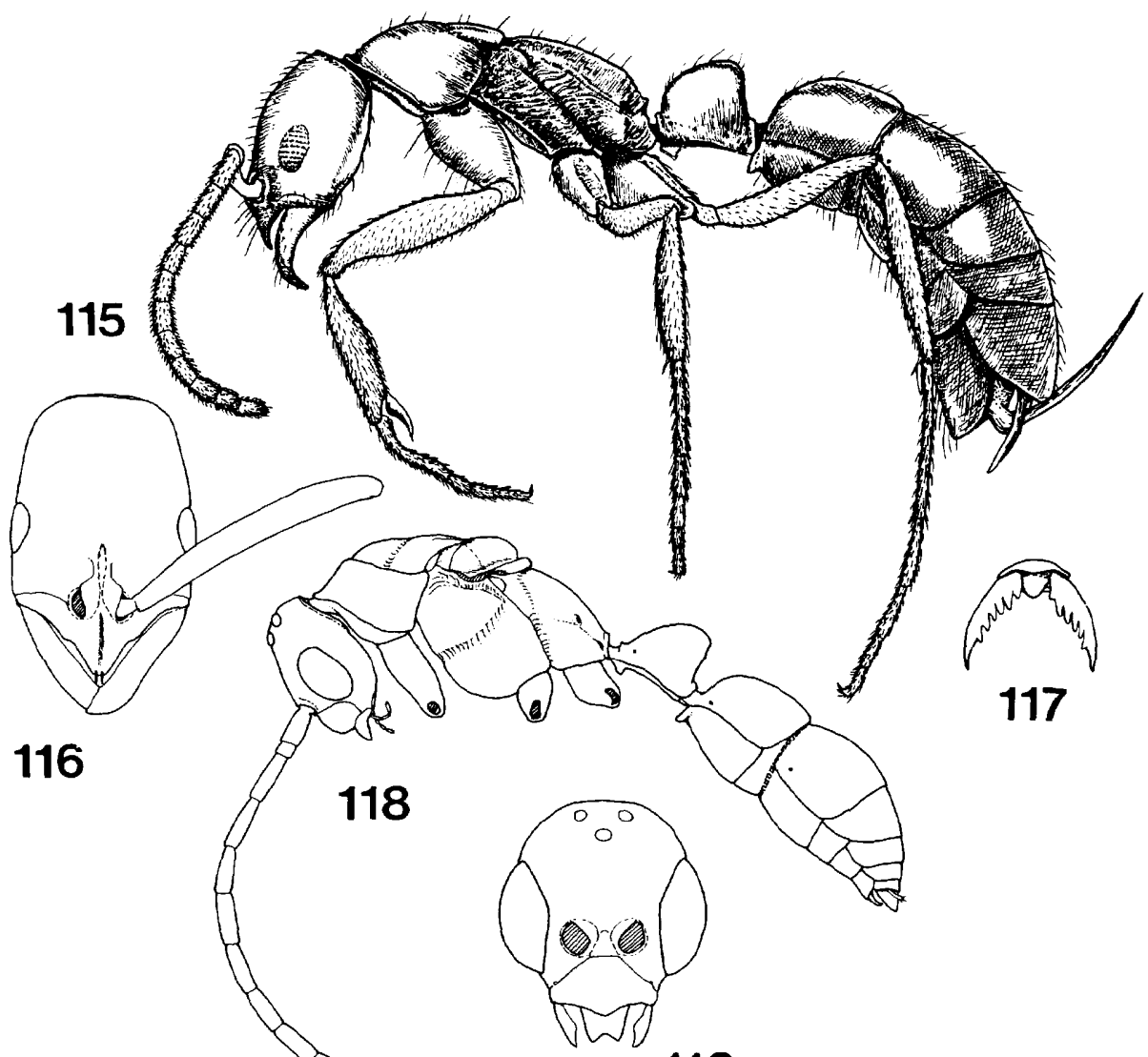

Figs. 115-119. Leptogenys confucii (115-117, worker ; 118119, male) : 115, profile ; 116, head ; 117 , middle tarsal claw ; 118, profile ; 119, head.

gular lobes, non-opposable. Palp formula 6,$4 ; 5,4 ;$ (Bolton, 1975), or 4, 3 in Japanese confucii. Clypeus large, convex ; anterior margin produced medially. Antennal insertions close to posterior margin of clypeus. Antenna 13-segmented, filiform ; scape short ; funiculus somewhat robust. Eyes large ; inner margin not sinuate. Ocelli small.

Mesonotum weakly convex dorsally; notauli and parapsidal furrows present ; mesoscutellum partly overhanging metanotum; oblique furrows impressed on mesepisternum ; epimeral lobe present ; propodeum with arched node and rounded posterior corners ; ventral processes developed as in worker. Fore wing with 2 closed cubital cells, single closed discoidal and radial cells ; anal lobe of hind wing lacking. Legs like those of worker. Petiolar node and subpetiolar process as in worker but with more rounded corners. Anteromedian portion of first gastric sternum and gastric constriction like those of worker ; pygidium without terminal spine. (Genitalia not dissected.)

Most of the species of the genus are found in the tropics and subtropics in the world. In his revision of the Ethiopian and Malagasy species, Bolton (1975) stated that there are 280 named forms 
which may represent abous 175 valid names. Comment on the genus was also given by Brown (1963).

In Japan 2 species has been reported. Of these, so far as I know, L. chinensis (Mayr) recorded by Dalla Torre (1893) is not found in Japan, though the species occurs in China and Taiwan. In fact Emery (1911), Teranishi (1940) and Onoyama (1976) excluded this species from the Japanese fauna. Thus, only one species is listed here :

\section{L. confucii Fore1}

The species was originally described from Taiwan. The occurrence of the species was first reported by Kubota (1984) from Cape Sata, Kagoshima Pref., and later by Terayama (1985) from the Nansei Islands. Probably L. sp. reported by Onoyama (1976) from Okinawa Island may be conspecific with this species.

\section{Genus Odontomachus Latreille}

(Figs. 120-133)

Odontomachus Latreille, 1804, Nouv. Dict. Hist. Natur. $24: 179 . \quad$ Type-species : Formica haematoda Linnaeus, 1758, Syst. Nat. ed. $10: 582$, by original designation.

Pedetes Bernstein, 1861, Verh. zool.-bot. Ges. Wien 11 : 7. Type-species : Pedetes macrorhynchus Bernstein, 1861, loc. cit., by monotypy. (Nomen nudum.)

Champsomyrmex Emery, 1892, Ann. Soc. ent. Fr. 60 : 558. Type-species: Odontomachus coquereli Roger, 1861, Berl. ent. Z. 5 : 30, by monotypy.

Myrtoteras Matsumura, 1918, Thousand Insects of Japan : 191. Type-species : Myrtoteras kuroiwae

Matsumura, 1918, loc. cit., by monotypy.

Worker : Head longer than broad, more or less constricted at posterior third of head. Mandibles elongate, linear, inserted close each other in the middle of anterior margin of head ; masticatory margin consisting of 3 larger apical teeth, the basal one of which is truncate, and a series of basal minute denticles ; basal articular condyle distinct. Palp formula 4, 4;4, 3 (Brown, 1976). Clypeus short, compressed laterally; anterior margin more or less produced in the middle. Frontal carinae covering antennal insertions to form frontal lobes anteriorly, and diverging posteriorly at the level of eyes. Antenna 12-segmented; scape long and slender, extending beyond posterior margin of head ; funiculus filiform. Eyes large, situated at the broadest part of lateral prominence dorsally. Posterior face marginate by low occipital carina with apophysial lines which is anterodorsally fused together to form median longitudinal furrow and posteriorly diverging at both sides of postocciput.

Trunk slender; promesonotal suture complete ; pro- and mesonotal areas raised ; metanotal groove impressed; propodeum elongate with arched node ; ventral processes usually developed on meso- and metasternum, but varying with species. Legs long and slender; middle and hind tibiae each with a large pectinate spur and a smaller simple spur ; claws simple in Japanese species. Petiolar node conical, ending acute apical point dorsally ; subpetiolar process usually distinct. Gaster not truncate anteriorly ; first gastric sternum with distinct projection anteriorly ; gastric constriction between first and second segments indistinct ; sting developed.

Female : Unknown to me.

Male : Head subglobose, somewhat depressed dorsoventrally. Mandibles small, non-opposable, each with acute apex. Palp formula 5, 4 in Japanese species. Clypeus large, convex, with almost straight anterior margin. Antennal insertion apart from posterior margin of clypeus. Antenna 13segmented, filiform ; scape short ; third antennal segment longest. Eyes large and prominent ; inner margin sinuate. Ocelli well developed.

Mesoscutum slightly convex; parapsidal furrow present, notauli usually present, but absent in Japanese species ; mesoscutellum well convex, partly overhanging metanotum ; oblique furrow im- 


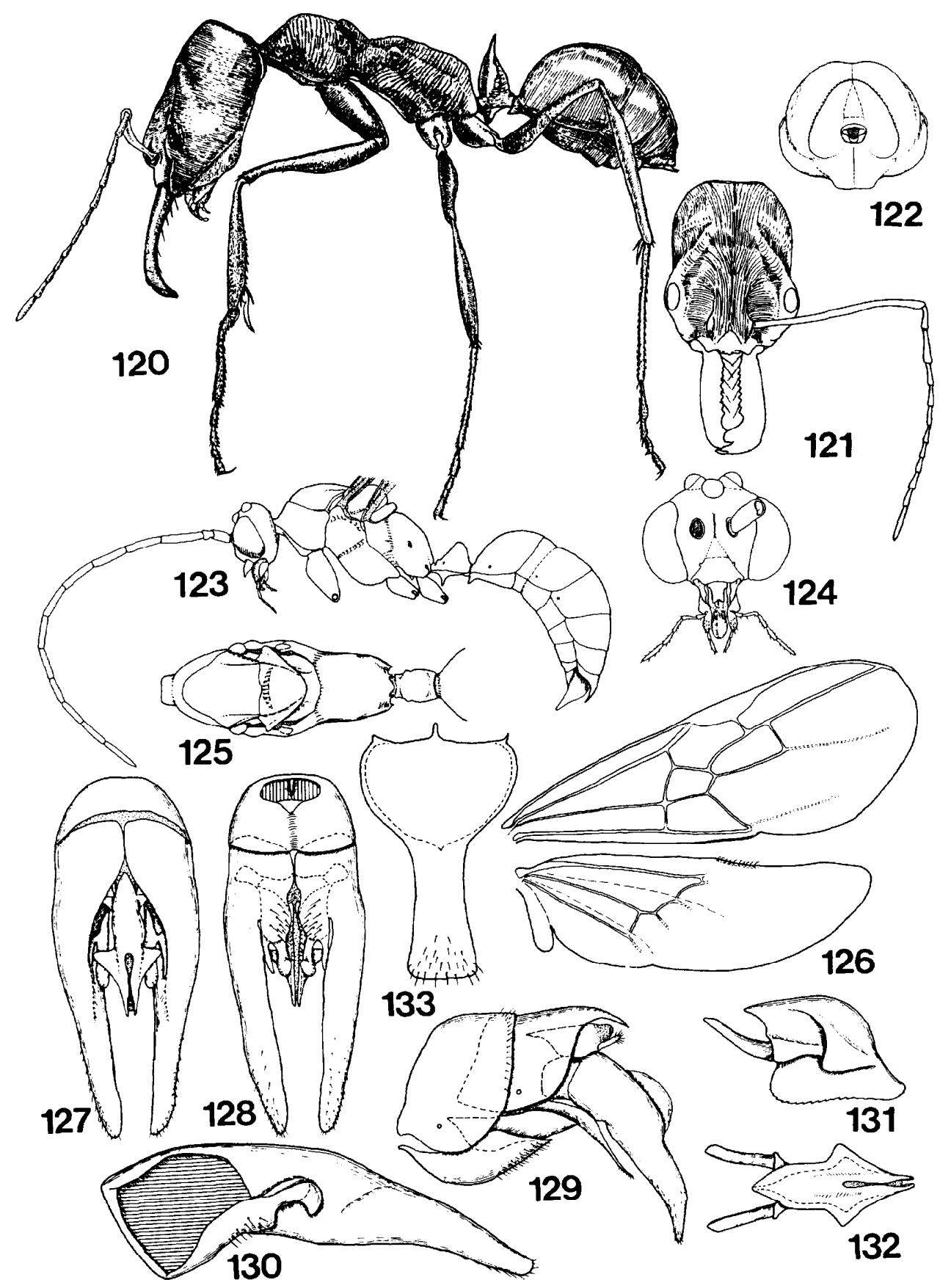

Figs. 120-133. Odontomachus monticola (120-122, worker ; 123-133, male) : 120, profile ; 121, head ; 1 '22, same, caudal view ; 123 , profile ; 124 , head ; 125 , trunk, dorsal view ; 126, right wings ; 127 , genitalia, dorsal view ; 128, same, ventral view ; 129, terminal segments ; 130, right paramere and volsella ; 131, left aedeagal plate, lateral view ; 132, same, dorsal view ; 133, subgenital plate. 
pressed on mesepisternum; epimeral lobe distinct ; propodeum elongate, with rounded node ; ventral processes present as in worker. Fore and hind wings as in Fig. 126 ; anal lobe of hind wing present. Legs as in worker, but claws usually toothed. Petiolar node tapering with blunt tip ; subpetiolar process more pointed than that of worker. First gastric segment as in worker ; gastric constriction more or less distinct ; pygidium with distinct terminal spine. Hypopygium elongate, with half elliptical basal portion and rectangular-y projected distal portion. Genitalia not retractile ; basal ring thick, with longitudinal inner ridge dorsomedially ; paramere long and slender, tapering toward apex ; volsella with short but distinct digitus and cuspis; aedeagal plate short, with serrate ventral margin and laterally produced shelf, the latter which covers a part of digitus.

The genus is distributed in the tropics and subtropics of the world. Brown $(1976,1978)$ revised the genus and listed 51 species in the world. The Melanesian species were studied by Wilson (1959).

In Japan the genus has been represented by a single species :

0. monticola Emery

This species is widely spread through the Oriental Region, but restricted in Yakushima Island and the Ryukyus in Japan.

\section{Subfamily CERAPAChyinAE}

Cerapachysii Forel, 1893, Ann. Soc. ent. Belg. 37: 162.

Cerapachyinae Wheeler, 1920, Psyche $27: 51$.

Worker : Antennal insertion exposed, encircled by lateral carina which is sometimes forming small lateral process above mandibular base. Antennal scape distinctly clavate. Occipital carina low, usually running ventrally from each dorsal corners. Trunk compact, with subparallel sides and flattened node. Abdominal pedicel one-segmented, thick, usually cylindrical or square form. Gastric constriction between first and second segments distinct. Pygidium with denticulate margination posteriorly.

Female (ergatomorphic form) : General form of body and appendages like those of worker, except for having developed eyes, ocelli and larger size. Winged form unknown to me.

Male : Mandibles developed. Trunk rigid with or without natauli. Fore wing with highly variable venation, sometimes distal portion of Rs and $\mathrm{M}$ reduced ; hind wing lacking anal lobe. Petiole thick, with more rounded node. Pygidium without denticulate margination; terminal spine absent. Hypopygium with paired projection apically. Genitalia retractile ; paramere without gonocoxal arm.

There is a disagreement as for the taxonomic ranking of this taxon. The subfamily, when first raised by Wheeler (1920), included 3 tribes ; Acanthostichini, Cerapachyini and Cylindromyrmecini. Later Wheeler (1922) removed the tribe Cylindromyrmecini to the subfamily Ponerinae. But Brown (1954) reincluded it to the Cerapachyinae, and more recently (1975) he reduced the taxon to 3 tribes within the Ponerinae. Wheeler and Wheeler (1985) opposed to Brown's lumping based on their larval study, and followed Wheeler (1922).

I think that this problem should be solved by the careful phylogenetic analysis. Since the monophyly of Ponerinae is not clear to me at present, here I follow Wheelers' treatment tentatively. It is felt that more detailed study on the relationship between taxa, especially the Dorylinae, Ecitoninae, Leptanillinae and Ponerinae is needed. 


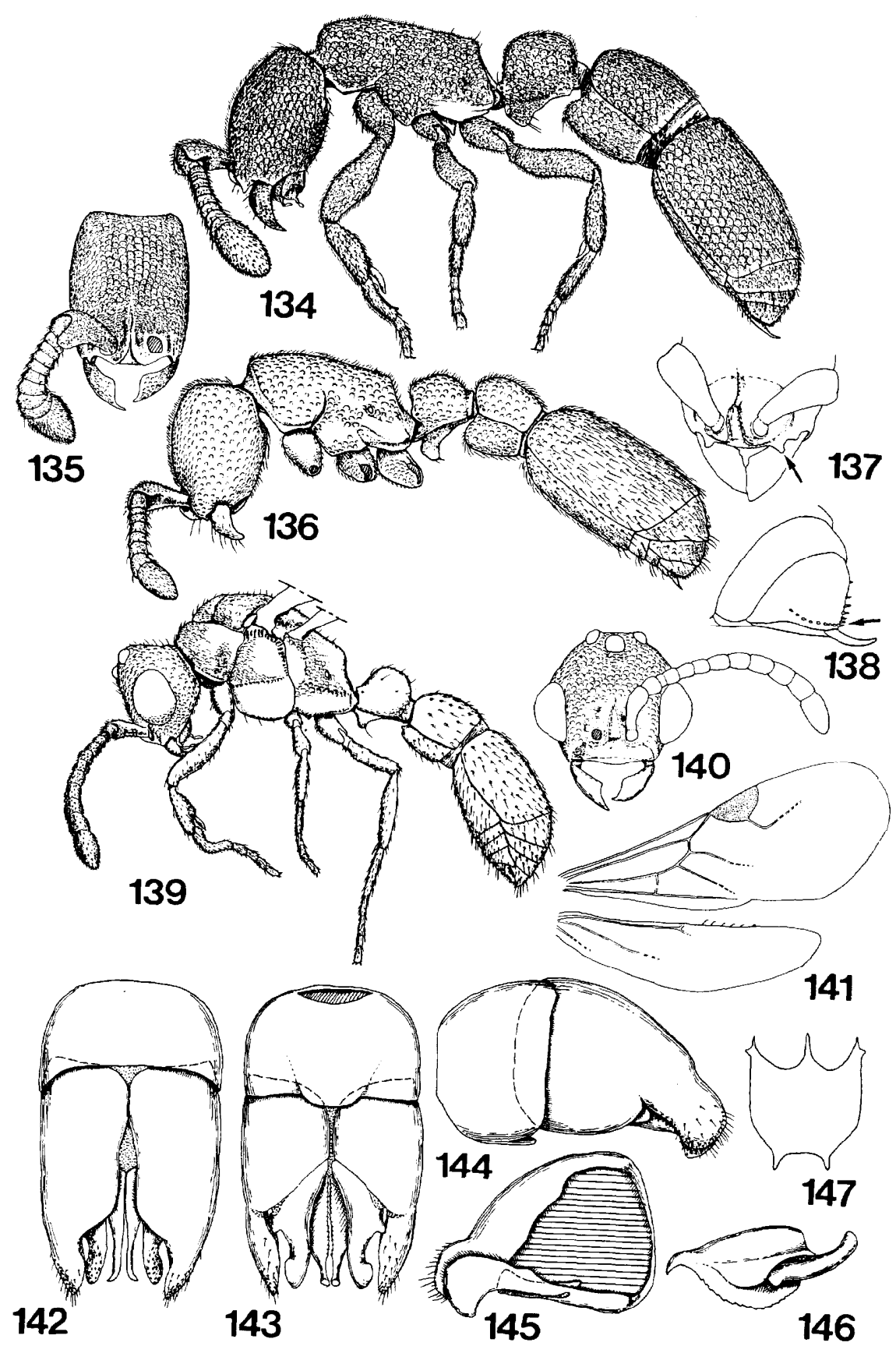

Figs. 134-147. Cerapachys spp. (134-138, worker; 139-147, male) : 134, C. humicola, profile; 135, same, head ; 136, C. biroi, profile; 137, same, mandibles; 138, same, pygidial denticles; 139, $C$. humicola, profile ; 140, same, head ; 141, same, right wings ; 142, same, genitalia, dorsal view ; 143, same, ventral view ; 144, same, lateral view ; 145 , left paramere and volsella ; 146, right aedeagal plate ; 147 , subgenital plate. 


\section{Genus Cerapachys F. Smith \\ (Figs. 134-147)}

Cerapachys F. Smith, 1857, J. Proc. Linn. Soc. 2: 74. Type-species : Cerapachys antennatus F. Smith, 1857, loc. cit., by monotypy.

Syscia Roger, 1861, Berl. ent. Z. 5 : 19. Type-species : Syscia typhla Roger, 1861, op. cit. : 20, by monotypy.

Syscia : Wilson, 1959, Pac. Ins. Mon. $1: 39$ (as a subgenus of Cerapachys).

O ocevaea Roger, 1862, Berl. ent. Z. 6 : 248. Type-species : O oceraea fragosa Roger, 1862, op. cit. : 249, by monotypy.

O oceraea : Emery, 1902, Rend. R. Accad. Sci. 1st. Bologna (n. s.) $6: 24$ (as a subgenus of Cerapachys).

Lioponera Mayr, 1878, Verh. zool.-bot. Ges. Wien $28: 666$. Type-species : Lioponera longitarsus Mayr, 1878, op. cit. : 667, by monotypy.

Parasyscia Emery, 1882, Species des Hymenoptera d'Europe et d'Algerie 2: 235. Type-species : Parasyscia piochardi Emery, 1882, loc. cit., by monotypy.

Phyracaces Emery, 1902, Rend. R. Accad. Sci. 1st. Bologna (n. s.) 6 : 23. Type-species : Cerapachys mayri Forel, 1892, Hist. Phys. nat. polit. Madagascar $20: 244$, by original designation.

Phyracaces : Forel, 1902, Rev. suisse Zool. 10:405 (as a subgenus of Cerapachys).

Cysias Emery, 1902, Rend. R. Accad. Sci. 1st. Bologna (n. s.) $6: 24$, (as a subgenus of Cerapachys). Type-species : O oceraea papuana Emery, 1879, Termes. Füzet. $20: 594$, by original designation.

Procerapachys Wheeler, 1914, Schrift. Phys. ökon. Ges. Königsberg 55:27. Type-species :Procerapachys annosus Wheeler, 1914, op. cit. : 28, by original designation.

Chrysapace Crawley, 1924, Ann. Mag. nat. Hist. (9) 13 : 380. Type-species : Cerapachys jacobsoni Forel, 1912, Notes Leyden Mus. $34: 104$, by original designation.

Chrysapace: Wheeler, 1924, Psyche 31: 225 (as a subgenus of Cerapachys).

Neophyracaces Clark, 1941, Mem. nat. Mus. Vict. Melbourne 12:71. Type-species: Phymcaces clarus Clark, 1930, Proc. R. Soc. Vict. Melbourne (n. s.) $43: 3$, by original designation.

Worker : Head subrectangular ; occipital carina distinct, especially on ventrolateral surface of head. Mandible subtriangular, with acute apex ; masticatory margin edentate, or with minute denticles. Palp formula from 4, 3 to 2, 2 (Brown, 1975). Clypeus narrow, depressed ; sometimes paired anterolateral projection present just above the mandibular insertions. Antennal carinae vertically raised and fused together, forming thin lamella. Antenna1 insertions exposed, situated anteriorly, and separated by median lamella. Area around antennal insertion flat or concave, forming ridge or carina laterally. Antenna 9- to 12-segmented ; scape clavate, short, usually not exceeding beyond posterior corner of head; funiculus thick, incrassate; apical segment bolbous. Eyes varying from large to minute in size, or often absent. Ocelli absent.

Trunk rigid ; dorsal outline straight ; pronotum sometimes marginate anteriorly, promesonotal suture usually absent dorsally; metanotal groove absent ; propodeum truncate posteriorly, often with posterior margination ; ventral processes usually present on metasternum, but low or absent on mesosternum. Legs robust; middle and hind tibiae each with a single pectinate spur, but without simple spur ; claws simple. Petiolar node thick, more or less fat above ; subpetiolar process present, but varying in shape with species. First gastric segment larger than second one; anteromedian portion of first gastric sternum concave, but not forming distinct margination; second gastric segment much larger than those following ; pygidium bearing a row of denticles posteriorly ; sting developed.

Female : Winged or dealated form unknown to me. Ergatomorphic female developed various 
degree in size of eyes and body, but general form as in worker.

Male : Head subglobose, with distinct occipital carina. Mandibles subtriangular, opposable ; masticatory margin edentate with acute apex. Palp formula, 4, 2 in Japanese species examined. Clypeus transverse, broader than that of worker ; anterior margin widely rounded, without anterolateral projections. Frontal carina raised but low. Antennal insertion situated anteriorly, more or less close to posterior margin of clypeus. Antenna usually 13-segmented, but 12-segmented in Japanese humicola; scape short and robust; funiculus incrassate. Eyes large and prominent ; inner margin sinuate. Ocelli developed.

Pronotum relatively small ; mesonotum convex ; notauli usually indistinct or absent, but distinct in Japanese humicola, parapsidal furrows present or absent ; mesoscutellum partly overhanging metanotum ; mesepistemum with oblique furrow ; epimeral lobe indistinct ; propodeum with short dorsal surface and more or less angulate posterodosal comers. Fore wing venation variable, usually with single closed discoidal and cubital cells, but absent in Japanese humicola. Ventral processes and legs like those of workers. Petiole as in worker, with more rounded node ; subpetiolar process lower than that of worker.

First and second gastric segments and gastric constriction like those of worker ; pygidium without terminal spine. Hypopygium with single median and paired lateral projections at basal margin, and with paired apical projections. Genitalia retractile ; basal ring thick, broader than long ; paramere with rounded apex ; volsella with large digitus and smaller cuspis; aedeagal plate subtriangular with serrate ventral margin and acute apex.

The genus is found in the tropical and subtropical regions of the world. According to Brown (1975), the genus contains about 140 species in the world. The ant is known as having a raiding behavior like army ants. Some behavioral observation was reported by Hölldobler (1982). No detailed biology of Japanese species has been studied.

In Japan the genus has been represented by 2 species :

C. biroi Fore 1

C. humicola Ogata

The former is distributed in the world tropics and subtropics, and in Japan it is restricted to the Ryukyus. The latter species is found in south-western area of Japan proper but rare. Ogata (1983) revised the Japanese species.

\section{References}

Abe, T. and K. Uezu, 1977. Biology of Diacamma rugosum (Le Guillou) in the Ryukyu Islands with special reference to foraging behavior. Proc. 8th Intr.Congr.IUSSI, Wageningen, pp. 142-143.

Baroni Urbani, C., 1978. Contributo alla conoscenza del genere Amblyopone Erichson. Mitt. schweiz. Ent. Ges., $51: 39-51$.

Bolton, B. 1975. A revision of the ant genus Leptogenys Roger (Hymenoptera : Formicidae) in the Ethiopian Region with a review of the Malagasy species. Bull.Brit.Mus.nat.Hist.(Ent.), 31: 237-305.

Brown, W. L., Jr., 1954. Remarks on the internal phylogeny and subfamily classification of the family Formicidae. Ins. soc., 1: 21-31.

- 1958a. Contributions toward a reclassification of the Formicidae II. Tribe Ectatommini. Bull. Mus.comp.Zool.Harv., 118 : 173-362.

—,1958b. A review of the ants of New Zealand (Hymenoptera). Acta hym., 1: 1-50.

— 1960. Contributions toward a reclassification of the Formicidae III. Tribe Amblyoponini. 
Bull. Mus.comp.Zool.Harv., 122: 145-230.

--, 1963. Characters and synonymies among the genera of ants, Pt. III. Some members of the tribe Ponerini. Breviora, (190) : 1-10.

-, 1973. A comparison of the Hylean and Congo-West African rain forest ant faunas. In "Tropical forest ecosystems in Africa and South America : A comparative review" (B. J. Meggers, E. S. Ayensu and W. D. Duckworth, eds.), pp. 161-185. Smithson. Inst. Press, Washington, D. C.

- 1974. A remarkable new island isolate in the ant genus Proceratium (Hymenoptera :Formicidae). Psyche, $81:$ 70-83.

-., 1975. Contributions toward a reclassification of the Formicidae. V. Ponerinae, tribes Platythyreini, Cerapachyini, Cylindromyrmecini, Acanthostichini, and Aenictogitini. Search, Ithaca, 5 : $1-115$.

- 1976. Contributions toward a reclassification of the Formicidae. VI. Ponerinae, tribe Ponerini, subtribe Odonthomachiti. Section A. Introduction, subtribal characters, genus O dontomachus. Stud. ent., $19: 67-171$.

- 1978. Contributions toward a reclassification of the Formicidae. VI. Ponerinae, tribe Ponerini, subtribe Odontomachiti. Section B. Genus Anochetus and bibliography. Stud. ent., 20 : 549 638.

- 1979. A remarkable new species of Proceratium with dietary and other notes on the genus (Hymenoptera, Formicidae). Psyche, 86: 337-346.

Dalla Torre, C. G. De, 1893. Formicidae (Heterogyna). Catalogus Hymenopterorum, Vol. 7. 289 pp. Engelmann, Leipzig.

Emery, C., 1911. Subfamily Ponerinae. In “Genera Insectorum” (P. Wytsman, ed.), fasc. 118. 125 pp, 3 pls.

Fukumoto, Y. and T. Abe, 1983. Social organization of colony movement in the tropical ponerine ant, Diacamma rugosum (Le Guillou). J.Ethol., 1: 101-108.

Hölldobler, B., 1982. Communication, raiding behavior and prey storage in Cerapachys (Hymenoptera : Formicidae). Psyche, 89 : 3-23.

Imai, H. T., 1971. Karyological studies of Japanese ants. II. Species differentiation in Aphaenogaster ; with special regard to their morphology, distribution and chromosomes. Mushi, Fukuoka, 44: 137-151, 3 pls.

— and M. Kubota, 1972. Karyological studies in Japanese ants (Hymenoptera, Formicidae). III. Karyotypes of nine species in Ponerinae, Formicinae and Myrmicinae. Chromosoma (Berl.), 37 : 193-200.

Kubota, M., 1984. Records of ants (4). Ari, (12) : 12. (In Japanese with English summary)

Masuko, K., 1981. Predatory behavior of some forest- dwelling ants. Nature and Insects, 16(3): 19-25. (In Japanese)

—, 1984. Studies on the predatory biology of Oriental dacetine ants (Hymenoptera : Formicidae). I. Some Japanese species of Strumigenys, Pentastruma,Epitritus and a Malaysian Labdogenys, with special reference to hunting tactics in short-mandibulate forms. Ins.soc., 31:429-451.

— and M. Terayama, 1984. Ants from Izu and Ogasawara Islands. Ari, (12) : 7-12. (In Japanese with English summary)

Ogata, K., 1983. The ant genus Cerapachys F. Smith of Japan, with description of a new species (Hymenoptera, Formicidae). Esakia, Fukuoka, (20) : 131-137.

—- Y. Hirashima, T. Miura, Y. Maeta, K. Yano and J. -H. Ko, 1985. Ants collected in pine forests infested by the pine needle gall midge in Korea (Hymenoptera, Formicidae) Esakia, Fukuoka, (23) : 159-163.

Onoyama, K., 1976. A preliminary study of the ant fauna of Okinawa-Ken, with taxonomic notes 
(Japan : Hymenoptera : Formicidae). Ecol. Stud. Nat. Cons. Ryukyu Isl., 2 : 121-141.

- 1980. An introduction to the ant fauna of Japan, with a check list (Hymenoptera, Formicidae). Kontyâ, Tokyo, $48: 193-212$.

Snelling, R. R., 1981. Systematics of social Hymenoptera. Social Ins., 2 : 369-453.

Sonobe, R., 1972. Ant fauna of Mt. Kirishima area. Ann. Rep. JIBP/CT-S for the fiscal of 1972 : 176-182. (In Japanese with English summary)

Taylor, R. W., 1965. A monographic revision of the rare tropicopolitan ant genus Probolomyrmex Mayr. Trans. R. ent. Soc. Lond., $117: 345-365$.

- 1967. A monographic revision of the ant genus Ponera Latreille (Hymenoptera : Formicidae). Pac. Ins. Mon., 13 : 1-112.

—, 1978. Nothomyrmeciamacrops: a living-fossil ant rediscovered. Science, 201: 979-985.

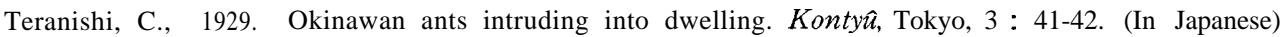

—, 1933. Japanese ants, their behavior and distribution (III). Trans. Kansai ent. Soc., (3) : 49-54. (In Japanese)

--, 1940. Works of Cho Teranishi, posthumous section. 95 pp. Osaka. (In Japanese)

Terayama, M., 1982a. Regional differences of the ant fauna of the Nansei Archipelago based on the quantitative method. I. Analysis using Nomura-Simpson's coefficient. Bull. biogeogr. Soc. Japan, $37: l-5$.

- 1982b. Regional differences of the ant fauna of the Nansei Archipelago based on the quantitative method. II. Analysis using harmonity index of taxon. Ibid., 37:7-10.

- 1985. New records of some ant from Nansei Islands, Japan. Ari, (13) : 8. (In Japanese with English summary)

Uezu, K., 1977. On the foraging activity of Diacamma mgosum. Biol. Mag. Okinawa, 15 : 5-17. (In Japanese)

Wheeler, G. C. and J. Wheeler, 1985. A simplified conspectus of the Formicidae. Trans. Amer. ent. Soc., 111: 255-264.

Wheeler, W. M., 1922. Ants of Belgian Congo, Part VII. Keys to the genera and subgenera of ants. Bull. Amer. Mus. nat. Hist. 45 : 631-710.

Wilson, E. O., 1958a. Studies on the ant fauna of Melanesia. I. The tribe Leptogenyini. II. The tribes Amblyoponini and Platythyreini. Bull. Mus. comp. Zool. Harv., 118 :101-153.

- 1958b. Studies on the ant fauna of Melanesia. III. Rhytydoponera in Western Melanesia and the Moluccas. IV. The tribe Ponerini. Ibid., $119: 303-371$.

- 1959. Studies on the ant fauna of Melanesia. V. The tribe Odontomachini. Ibid., 120 : 483-510, 2 pls.

Yamauchi, K., K. Kinomura and S. Miyake, 1981. Sociobiological studies of the polygynic ant Lasius sakagamii. I. General features of its polydomous system. Ins. soc. 28 : 279-296.

— and — 1982. Sociobiological studies of the polygynic ant Lasius sakugamii. II. Production of colony members, Ibid., 29: 164-174.

Yasumatsu, K., 1962. Notes on synonymies of five ants widely spread in the Orient (Hymenoptera : Formicidae). Mushi, Fukuoka, $36:$ 93-97. 